Published in "Journal of Inorganic Biochemistry 195(): 149-163, 2019"

which should be cited to refer to this work.

\title{
Silver(I) complexes with 4,7-phenanthroline efficient in rescuing the zebrafish embryos of lethal Candida albicans infection
}

\author{
Aleksandar Pavic $^{\mathrm{a}, *, 1}$, Nada D. Savić ${ }^{\mathrm{b}, *, 1}$, Biljana Đ. Glišicic ${ }^{\mathrm{b}}$, Aurélien Crochet $^{\mathrm{c}}$, Sandra Vojnovic ${ }^{\mathrm{a}}$, \\ Atanas Kurutos ${ }^{\mathrm{d}}$, Dalibor M. Stankoviće ${ }^{\mathrm{e}}$ Katharina M. Fromm ${ }^{\mathrm{c}}$, Jasmina Nikodinovic-Runic ${ }^{\mathrm{a}}$, \\ Miloš I. Djuran ${ }^{\mathrm{f}, *}$
}

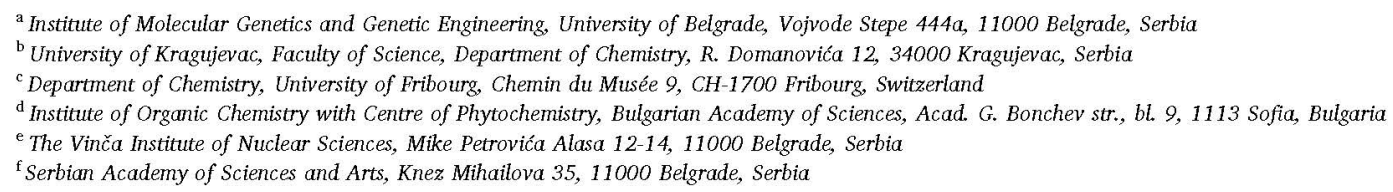

\section{Introduction}

Having transitioned from a rare incidence to an everyday problem, invasive fungal infections are a rapidly increasing global threat to human health. In the developed world, fungal infections predominantly occur in the context of increasingly aggressive immunosuppressive therapies. Disseminated candidiasis is the 4th leading infection in hospitalized patients in the United States and Europe, surpassing many bacterial pathogens, with the mortality rates remaining disturbingly high at $40 \%$ [1]. $>90 \%$ of invasive infections are caused namely by Candida albicans, C. glabrata, C. parapsilosis and C. krusei [2,3]. Unfortunately, therapeutic options for fungal infections are limited as only four classes of compounds are currently used in clinical practice, and only one new class of antifungal agent has been developed in the last thirty years [4]. Nevertheless, each drug class has significant therapeutic limitations, ranging from serious systemic toxicity (amphoter-

\footnotetext{
* Corresponding authors.

E-mail addresses: sasapavic@imgge.bg.ac.rs (A. Pavic), nada.savic@kg.ac.rs (N.D. Savić), djuran@kg.ac.rs (M.I. Djuran).

${ }^{1}$ A.P. and N.D.S. contributed equally.
} 
icin B and nystatin), hepatotoxicity and/or nephrotoxicity (amphotericin B and its formulations, flucytosine, itraconazole, voriconazole) to drug resistance (particularly azoles) or limited routes of administration (echinocandins) [5]. The limited efficacy in the treatment of lifethreatening fungal infections, accompanied with the emergence of antifungal-resistant strains, highlights the urgent need for the development of new antifungal agents, particularly new structures that act upon novel targets or that could overcome the resistance.

Metal-based antifungal complexes present very attractive therapeutics in the era of antibiotic resistance [6], since their mechanisms of activity fundamentally differ from those of clinically used antifungal drugs, thus exerting less selective pressure on the pathogen resistance development. Among them, some metal complexes showed comparable or even higher activity against different Candida spp. in comparison to the commercial antifungal drugs, making them interesting and valued candidates for the application in the antifungal therapy [7]. Moreover, it has been demonstrated that some of these complexes had improved antifungal activity in comparison to antifungals currently in clinical use when applied in combination therapy [7]. Such strategy has been proven to offer the advantage not only in an improved anti-Candida activity, but also in reduced toxicity and the likelihood of appearance of resistance [8]. Among metal complexes which have shown remarkable antifungal potential, silver(I) species have attracted considerable attention due to the low toxicity of $\mathrm{Ag}(\mathrm{I})$ ion to mammals and high toxicity to microorganisms [9]. Different classes of ligands have been utilized for the synthesis of antifungal silver(I) complexes, and, among them, aromatic nitrogen-containing heterocycles ( $N$-heterocycles) have formed the complexes showing significant anti-Candida potential [10-16].

Since the discovery of the considerable anti-Candida activity of 1,10-phenanthroline (1,10-phen), diverse silver(I) complexes with 1,10-phen as a ligand have been synthesized and proven as potent inhibitors of Candida albicans growth, with the minimal inhibitory concentrations (MICs) being in the range from 0.5 to $9 \mu \mathrm{M}$ [13]. However, the most potent complex among them, $\left[\mathrm{Ag}(1,10 \text {-phendio })_{2}\right] \mathrm{ClO}_{4}(1,10$ phendio is 1,10-phenanthroline-5,6-dione), with an impressive antifungal activity (MIC $=0.5 \mu \mathrm{M}$ ), appeared to be hepatocytotoxic already at the sub-therapeutic doses $\left(\mathrm{IC}_{50}=0.3 \mu \mathrm{M}\right)$, while next one by the potency, $\quad\left[\mathrm{Ag}_{2}(1,10 \text {-phen })_{3}(\mathrm{mal})\right] \cdot 2 \mathrm{H}_{2} \mathrm{O} \quad\left(\mathrm{MIC}=5.6 \mu \mathrm{M} ; \quad \mathrm{H}_{2} \mathrm{mal} \quad\right.$ is malonic acid), was not effective in vivo in C. abicans-Galleria mellonella infection model and drastically increased the number of immune cells as the hallmark of an inflammatory response [13]. The antifungal efficacy of the other 1,10-phen-based metal complexes, to the best of our knowledge, has never been addressed in vivo.

Although $N$-heterocycles 1,7-phenanthroline (1,7-phen) and 4,7phenanthroline (4,7-phen) showed no antifungal activity and therefore, have not been in the focus of interest for synthesis of novel anti-Candida complexes, we have recently demonstrated the remarkable antifungal potential of mononuclear silver(I) complexes with 1,7-phen i் vitro and good toxicological profile in the zebrafish animal model [14]. Prompted by such success, in this study we have synthesized a series of novel 4,7phen derived silver(I) complexes, $\left[\mathrm{Ag}\left(\mathrm{NO}_{3}-\mathrm{O}\right)(4,7 \text {-phen- } \mu-N 4, N 7)\right]_{\mathrm{n}}(1)$, $\left[\mathrm{Ag}\left(\mathrm{ClO}_{4}-\mathrm{O}\right)(4,7-\mathrm{phen}-\mu-\mathrm{N} 4, \mathrm{~N} 7)\right]_{\mathrm{n}} \quad(2), \quad\left[\mathrm{Ag}\left(\mathrm{CF}_{3} \mathrm{COO}-\mathrm{O}\right)(4,7-\right.$ phen- $\mu-$ $N 4, N 7)]_{\mathrm{n}}(3),\left[\mathrm{Ag}_{2}\left(\mathrm{H}_{2} \mathrm{O}\right)_{0.58}(4,7-\mathrm{phen})_{3}\right]\left(\mathrm{SbF}_{6}\right)_{2}$ (4) and $\left\{\left[\mathrm{Ag}_{2}\left(\mathrm{H}_{2} \mathrm{O}\right)\right.\right.$ (4,7-phen- $\left.\left.\mu-N 4, N 7)_{2}\right]\left(\mathrm{BF}_{4}\right)_{2}\right\}_{\mathrm{n}}$ (5), and demonstrated their enhanced activity against $C$. abicans, as well as improved therapeutic profile than it has previously been shown for any reported silver(I) complex with 1,10- and 1,7-phen [13-16]. Moreover, the complexes 1, 3 and 5, which showed the best therapeutic profiles, were evaluated for their antifungal efficacy in vivo in the C. albicans-zebrafish infection model, and to the best of our knowledge, this is the first study demonstrating the anti-Candida efficacy of metal-phenanthroline complexes in an animal model. In order to shed more light on the mechanism of the complexes' action, DNA interactions and the production of reactive oxygen species (ROS) in C. albicans cells were also investigated.

\section{Experimental section}

\subsection{Materials}

Silver(I) salts $\left(\mathrm{AgNO}_{3}, \mathrm{AgClO}_{4}, \mathrm{AgCF}_{3} \mathrm{COO}, \mathrm{AgSbF}_{6}\right.$ and $\left.\mathrm{AgBF}_{4}\right), 4,7-$ phenanthroline (4,7-phen), methanol, ethanol, acetone, dimethyl sulfoxide (DMSO), dimethylformamide (DMF), deuterated solvents - dimethylformamide (DMF- $d_{7}$ ) and dimethyl sulfoxide (DMSO- $d_{6}$ ) were purchased from the Sigma-Aldrich Chemical Co. All the employed chemicals were of analytical reagent grade and used without further purification.

\subsection{Measurements}

Elemental microanalyses of the synthesized $\mathrm{Ag}(\mathrm{I})$ complexes for carbon, hydrogen and nitrogen were performed by the Microanalytical Laboratory, Faculty of Chemistry, University of Belgrade and Adolphe Merkle Institute, University of Fribourg. All NMR spectra were recorded at $25^{\circ} \mathrm{C}$ on a Bruker Avance III $400 \mathrm{MHz}$ spectrometer $\left({ }^{1} \mathrm{H}\right.$ at $400 \mathrm{MHz}$, ${ }^{13} \mathrm{C}$ at $\left.101 \mathrm{MHz}\right) .5 .0 \mathrm{mg}$ of each compound was dissolved in $0.6 \mathrm{~mL}$ of DMF- $d_{7}$ and transferred into a $5 \mathrm{~mm}$ NMR tube. Chemical shifts are expressed in ppm $(\delta)$ and scalar couplings are reported in Hertz $(J)$. Chemical shifts were calibrated relative to those of the solvent. In order to investigate the solution behavior of silver(I) complexes, the ${ }^{1} \mathrm{H}$ NMR spectra were recorded immediately after their dissolution in DMSO- $d_{6}$ (DMSO is used for biological evaluation), as well as after $24 \mathrm{~h}$ standing in the dark at room temperature. The $\mathbb{R}$ spectra were recorded as $\mathrm{KBr}$ pellets on a Perkin-Elmer Spectrum One FT-IR spectrometer over the wavenumber range of $4000-450 \mathrm{~cm}^{-1}$. The UV-Vis spectra were recorded over the wavelength range of $900-200 \mathrm{~nm}$ on a Shimadzu UV1800 spectrophotometer after dissolving the silver(I) complexes in DMF/ $\mathrm{H}_{2} \mathrm{O}$ and DMF/RPMI medium (RPMI medium is Roswell Park Memorial Institute medium) with $2 \%$ of glucose (v/v 1: 9 ) at room temperature, as well as after $24 \mathrm{~h}$. The concentration was in the range of $1.25-6.40 \cdot 10^{-5} \mathrm{M}$. The ESI-MS spectra in positive mode were recorded after dissolving the silver(I) complexes in $\mathrm{DMF} / \mathrm{H}_{2} \mathrm{O}(1: 9, \mathrm{v} / \mathrm{v})$ with a Bruker Esquire Ion Trap mass spectrometer. The voltammetric measurements were performed using a potentiostat/galvanostat $(\mathrm{CH}$ Instruments, USA). The cell ( $5 \mathrm{~mL}$ ) consisted of a three-electrode system, a boron doped diamond electrode (Windsor Scientific, UK, boron doping level $1000 \mathrm{ppm}$ and resistivity $0.075 \Omega$ ) as a working electrode, a $\mathrm{Ag} /$ $\mathrm{AgCl}$ (saturated $\mathrm{KCl}$ ) as a reference electrode and a Pt wire as a counter electrode. All reported potentials are referred versus the $\mathrm{Ag} / \mathrm{AgCl}$ (saturated $\mathrm{KCl}$ ) reference electrode. Molar conductivities were measured at room temperature on a digital conductivity-meter Crison Multimeter MM 41. The concentration of the solutions of silver(I) complexes in DMSO and DMF used for conductivity measurements was $1 \cdot 10^{-3} \mathrm{M}$.

\subsection{Synthesis of siver (1) complexes}

\subsubsection{Synthesis of silver(I) complexes 1,3 and 5}

Silver(I) complexes $\left[\mathrm{Ag}\left(\mathrm{NO}_{3}-\mathrm{O}\right)(4,7-\text { phen }-\mu-N 4, N 7)\right]_{\mathrm{n}} \quad(1), \quad[\mathrm{Ag}$ $\left(\mathrm{CF}_{3} \mathrm{COO}-\mathrm{O}\right)(4,7-$ phen- $\left.\mu-N 4, N 7)\right]_{\mathrm{n}} \quad(3)$ and $\left\{\left[\mathrm{Ag}_{2}\left(\mathrm{H}_{2} \mathrm{O}\right)(4,7-\right.\right.$ phen- $\mu$ $\left.\left.N 4, N 7)_{2}\right]\left(\mathrm{BF}_{4}\right)_{2}\right\}_{n}(5)$ were synthesized according to the modified procedure for the preparation of silver(I) complexes with diazanaphthalenes [17]. A solution of 4,7-phen $(36.0 \mathrm{mg}, 0.2 \mathrm{mmol})$ in $10 \mathrm{~mL}$ of warm acetone was added slowly with stirring to a solution containing $0.4 \mathrm{mmol}$ of the corresponding silver(I) salt $\left(67.9 \mathrm{mg}\right.$ of $\mathrm{AgNO}_{3}$ for $\mathbf{1}$, $88.4 \mathrm{mg}$ of $\mathrm{AgCF}_{3} \mathrm{COO}$ for 3 and $77.9 \mathrm{mg}$ of $\mathrm{AgBF}_{4}$ for 5) dissolved in $10 \mathrm{~mL}$ of warm methanol. The reaction mixture was stirred in the dark at room temperature for $3 \mathrm{~h}$. The white precipitate that formed immediately on addition of 4,7-phen was filtered off and dissolved in the corresponding solvent (acetonitrile for 1, ethanol for $\mathbf{3}$ and methanol for 5 ). The obtained solution was left to evaporate slowly at room temperature. After 3-5 days, colorless crystals of 1, 3 and 5, suitable for single crystal X-ray analysis were formed. Yield (calculated on the basis 
of $N$-heterocyclic ligand): $52.5 \mathrm{mg}(75 \%)$ for $\mathbf{1}, 50.5 \mathrm{mg}(63 \%)$ for 3 and $69.8 \mathrm{mg}(87 \%)$ for 5.

Anal. calcd for $1=\mathrm{C}_{12} \mathrm{H}_{8} \mathrm{AgN}_{3} \mathrm{O}_{3}(\mathrm{MW}=350.08)$ : C, 41.17; $\mathrm{H}$, $2.30 ; \mathrm{N}, 12.00$. Found: $\mathrm{C}, 40.83 ; \mathrm{H}, 2.14 ; \mathrm{N}, 12.01 \%$. ${ }^{1} \mathrm{H}$ NMR $\left(400 \mathrm{MHz}, \mathrm{DMF}-d_{7}\right): \delta=8.06(d d, J=8.4,4.4 \mathrm{~Hz}, \mathrm{H} 1$ and $\mathrm{H} 10), 8.53$ (s, $\mathrm{H} 5$ and H6), 9.32 ( $d d, J=4.4,1.6 \mathrm{~Hz}, \mathrm{H} 2$ and $\mathrm{H} 9$ ), 9.63 ( $d d, J=8.4$, $1.5 \mathrm{~Hz}, \mathrm{H} 3$ and H8) ppm. ${ }^{13} \mathrm{C}$ NMR (101 MHz, DMF- $\left.d_{7}\right): \delta=122.80$ (C1 and $\mathrm{C} 10$ ), 125.46 (C1a and $\mathrm{C} 10 \mathrm{a}$ ), 132.37 (C3 and C8), 132.41 (C5 and C6), 147.60 (C4a and C6a), 151.67 (C2 and C9) ppm. IR ( $\mathrm{KBr}, \nu, \mathrm{cm}^{-1}$ ): $3077 \mathrm{w}, 2920 \mathrm{w}\left(\nu\left(\mathrm{C}_{\mathrm{ar}}-\mathrm{H}\right)\right), 1619 \mathrm{w}, 1582 \mathrm{w}, 1524 \mathrm{w}, 1497 \mathrm{~s}, 1441 \mathrm{~m}$ $\left(v\left(\mathrm{C}_{\mathrm{ar}}=\mathrm{C}_{\mathrm{ar}}\right)\right.$ and $\left.v\left(\mathrm{C}_{\mathrm{ar}}=\mathrm{N}\right)\right), 1384 \mathrm{vs}$ and $1301 \mathrm{~s}\left(v_{\mathrm{as}}\left(\mathrm{NO}_{3}\right)\right), 828 \mathrm{~m}$, $794 \mathrm{~m} \quad\left(\gamma\left(\mathrm{C}_{\mathrm{ar}}-\mathrm{H}\right)\right)$. UV-Vis $\quad\left(\mathrm{DMF} / \mathrm{H}_{2} \mathrm{O}, \quad \lambda_{\max }, \quad \mathrm{nm}\right): 272.0$ $\left(\varepsilon=2.4 \cdot 10^{4} \mathrm{M}^{-1} \mathrm{~cm}^{-1}\right)$. ESI ${ }^{+}$-MS $\left(\mathrm{DMF} / \mathrm{H}_{2} \mathrm{O}\right) \mathrm{m} / \mathrm{z}$ (relative in$\begin{array}{lllll}\text { tensity): } \quad 468.0 \quad\left[\mathrm{Ag}(4,7-\mathrm{phen})_{2}\right]^{+} & (100) . & \Lambda_{\mathrm{M}} & \text { (DMSO): }\end{array}$ $37.4 \Omega^{-1} \mathrm{~cm}^{2} \mathrm{~mol}^{-1} ; \Lambda_{\mathrm{M}}$ (DMF): $81.3 \Omega^{-1} \mathrm{~cm}^{2} \mathrm{~mol}^{-1}$.

Anal. calcd for $3=\mathrm{C}_{14} \mathrm{H}_{8} \mathrm{AgF}_{3} \mathrm{~N}_{2} \mathrm{O}_{2}$ (MW $=401.09$ ): $\mathrm{C}, 41.92 ; \mathrm{H}$, $2.30 ; \mathrm{N}, 6.98$. Found: $\mathrm{C}, 42.28 ; \mathrm{H}, 2.14 ; \mathrm{N}, 6.95 \% .{ }^{1} \mathrm{H}$ NMR $(400 \mathrm{MHz}$, DMF- $d_{7}$ ): $\delta=8.06$ ( $d d, J=8.4,4.4 \mathrm{~Hz}, \mathrm{H} 1$ and H10), 8.53 (s, H5 and H6), $9.32(d d, J=4.4,1.6 \mathrm{~Hz}, \mathrm{H} 2$ and $\mathrm{H} 9), 9.62(d d, J=8.4,1.5 \mathrm{~Hz}$, $\mathrm{H} 3$ and H8) ppm. ${ }^{13} \mathrm{C}$ NMR (101 MHz, DMF- $\left.d_{7}\right): \delta=122.76(\mathrm{Cl}$ and C10), 125.52 ( $\mathrm{Cla}$ and $\mathrm{C} 10 \mathrm{a}$ ), 132.36 ( $\mathrm{C} 3$ and $\mathrm{C} 8$ ), 132.40 (C5 and C6), 147.62 (C4a and C6a), 151.62 (C2 and C9) ppm. $\mathbb{R}\left(\mathrm{KBr}, \nu, \mathrm{cm}^{-1}\right.$ ): $3076 \mathrm{w}, 2925 \mathrm{w}\left(\nu\left(\mathrm{C}_{\mathrm{ar}}-\mathrm{H}\right)\right), 1691 \mathrm{vs}(\nu(\mathrm{C}=\mathrm{O})), 1584 \mathrm{w}, 1495 \mathrm{~m}, 1444 \mathrm{~m}$ $\left(v\left(\mathrm{C}_{\mathrm{ar}}=\mathrm{C}_{\mathrm{ar}}\right)\right.$ and $\left.v\left(\mathrm{C}_{\mathrm{ar}}=\mathrm{N}\right)\right), 1207 \mathrm{~s}\left(\nu_{\mathrm{s}}\left(\mathrm{CF}_{3}\right)\right), 1167 \mathrm{~s}\left(\nu_{\mathrm{as}}\left(\mathrm{CF}_{3}\right)\right), 1105 \mathrm{~s}$ $(\nu(C-O)), 834 \mathrm{~m}, 798 \mathrm{~m}\left(\gamma\left(\mathrm{C}_{a r}-\mathrm{H}\right)\right)$. UV-Vis $\left(\mathrm{DMF} / \mathrm{H}_{2} \mathrm{O}, \lambda_{\max }, \mathrm{nm}\right)$ : $272.0\left(\varepsilon=1.2 \cdot 10^{4} \mathrm{M}^{-1} \mathrm{~cm}^{-1}\right)$. ESI ${ }^{+}-\mathrm{MS}\left(\mathrm{DMF} / \mathrm{H}_{2} \mathrm{O}\right) \mathrm{m} / \mathrm{z}$ (relative $\begin{array}{lllll}\text { intensity): } \quad 468.0 \quad\left[\mathrm{Ag}(4,7-\text { phen })_{2}\right]^{+} & (100) . & \Lambda_{\mathrm{M}} & \text { (DMSO): }\end{array}$ $36.5 \Omega^{-1} \mathrm{~cm}^{2} \mathrm{~mol}^{-1} ; \Lambda_{\mathrm{M}}$ (DMF): $79.5 \Omega^{-1} \mathrm{~cm}^{2} \mathrm{~mol}^{-1}$.

Anal. calcd for $\mathbf{5}=\mathrm{C}_{24} \mathrm{H}_{18} \mathrm{Ag}_{2} \mathrm{~B}_{2} \mathrm{~F}_{8} \mathrm{~N}_{4} \mathrm{O}$ ( $\mathrm{MW}=767.78$ ): C, 37.54; $\mathrm{H}, 2.36 ; \mathrm{N}, 7.30$. Found: $\mathrm{C}, 37.28 ; \mathrm{H}, 2.15 ; \mathrm{N}, 7.35 \%$. ${ }^{1} \mathrm{H}$ NMR $\left(400 \mathrm{MHz}, \mathrm{DMF}-d_{7}\right): \delta=8.13(d d, J=8.4,4.5 \mathrm{~Hz}, \mathrm{H} 1$ and H10), 8.63 (s, $\mathrm{H} 5$ and H6), 9.39 (d, $J=4.4 \mathrm{~Hz}, \mathrm{H} 2$ and H9), 9.71 (d, $J=8.4 \mathrm{~Hz}, \mathrm{H} 3$ and H8) ppm. ${ }^{13} \mathrm{C}$ NMR (101 MHz, DMF- $\left.d_{7}\right): \delta=123.06$ (C1 and $\mathrm{C} 10$ ), 125.61 ( $\mathrm{C} 1 \mathrm{a}$ and $\mathrm{C} 10 \mathrm{a}$ ), 132.78 (C5 and $\mathrm{C} 6$ ), 132.92 (C3 and $\mathrm{C} 8$ ), 147.25 (C4a and C6a), 152.22 ( $\mathrm{C} 2$ and C9) ppm. IR (KBr, $\nu, \mathrm{cm}^{-1}$ ): 3445br $(\nu(\mathrm{O}-\mathrm{H})), 3081,2929 \mathrm{w}\left(\nu\left(\mathrm{C}_{\mathrm{ar}}-\mathrm{H}\right)\right), 1618 \mathrm{w}, 1585 \mathrm{~m}, 1521 \mathrm{w}$, $1495 \mathrm{~m}, 1444 \mathrm{~m}\left(\nu\left(\mathrm{C}_{\mathrm{ar}}=\mathrm{C}_{\mathrm{ar}}\right)\right.$ and $\left.v\left(\mathrm{C}_{\mathrm{ar}}=\mathrm{N}\right)\right), 1058 \mathrm{vs}\left(\nu\left(\mathrm{BF}_{4}\right)\right), 837 \mathrm{~m}$, $794 \mathrm{~m} \quad\left(\gamma\left(\mathrm{C}_{\mathrm{ar}}-\mathrm{H}\right)\right) . \quad \mathrm{UV}-\mathrm{Vis} \quad\left(\mathrm{DMF} / \mathrm{H}_{2} \mathrm{O}, \quad \lambda_{\max }, \quad \mathrm{nm}\right): 272.0$ $\left(\varepsilon=4.9 \cdot 10^{4} \mathrm{M}^{-1} \mathrm{~cm}^{-1}\right.$ ). ESI ${ }^{+}-\mathrm{MS} \quad\left(\mathrm{DMF} / \mathrm{H}_{2} \mathrm{O}\right) \mathrm{m} / \mathrm{z}$ (relative in$\begin{array}{lllll}\text { tensity): } \quad 468.0 \quad\left[\mathrm{Ag}(4,7-\text { phen })_{2}\right]^{+} & (100) . & \Lambda_{\mathrm{M}} & \text { (DMSO): }\end{array}$ $82.8 \Omega^{-1} \mathrm{~cm}^{2} \mathrm{~mol}^{-1} ; \Lambda_{\mathrm{M}}(\mathrm{DMF}): 165.7 \Omega^{-1} \mathrm{~cm}^{2} \mathrm{~mol}^{-1}$.

\subsubsection{Synthesis of silver(I) complexes 2 and 4}

Silver(I) complexes $\left[\mathrm{Ag}\left(\mathrm{ClO}_{4}-\mathrm{O}\right)(4,7-\text { phen- } \mu-\mathrm{N} 4, \mathrm{~N} 7)\right]_{\mathrm{n}} \quad$ (2) and $\left[\mathrm{Ag}_{2}\left(\mathrm{H}_{2} \mathrm{O}\right)_{0.58}(4,7-\mathrm{phen})_{3}\right]\left(\mathrm{SbF}_{6}\right)_{2}$ (4) were synthesized according to the modified procedure for the preparation of silver(I) complexes with 2,3-diphenylquinoxaline [18]. $20.0 \mathrm{~mL}$ of ethanolic solution of 4,7phen $(180.2 \mathrm{mg}, 1.0 \mathrm{mmol})$ was added dropwise with stirring at room temperature to an ethanolic solution $(5.0 \mathrm{~mL})$ of equimolar amount of the corresponding silver(I) salt $(207.3 \mathrm{mg} \mathrm{AgClO}$ for 2 and $343.6 \mathrm{mg}$ $\mathrm{AgSbF}_{6}$ for 4). The stirring was maintained for $3 \mathrm{~h}$ in the dark at room temperature. The precipitate that formed immediately on addition of 4,7-phen (for 2) was filtered off and dissolved in acetone/water ( $\mathrm{v} / \mathrm{v} 1$ : 1 ). The resulting solution was left to evaporate slowly at room temperature. After 3 days, the pale-yellow crystals of silver(I) complex 2 were collected. Colorless crystals of complex 4 suitable for X-ray analysis were obtained after evaporation of the mother liquor stored in a refrigerator at $+4^{\circ} \mathrm{C}$. These crystals were filtered off and dried in the dark at room temperature. Yield (calculated on the basis of $N$-heterocyclic ligand): $360.4 \mathrm{mg}$ (93\%) for 2 and $319.8 \mathrm{mg}$ (77\%) for 4.

Anal. calcd for $2=\mathrm{C}_{12} \mathrm{H}_{8} \mathrm{AgClN}_{2} \mathrm{O}_{4}(\mathrm{MW}=387.52)$ : $\mathrm{C}, 37.19 ; \mathrm{H}$, 2.08; N, 7.23. Found: C, 37.48; H, 2.16; N, 7.25\%. ${ }^{1} \mathrm{H} \mathrm{NMR}(400 \mathrm{MHz}$, DMF- $\left.d_{7}\right): \delta=8.17(d d, J=8.4,4.5 \mathrm{~Hz}, \mathrm{H} 1$ and $\mathrm{H} 10), 8.69$ (s, H5 and H6), $9.43(d d, J=4.5,1.5 \mathrm{~Hz}, \mathrm{H} 2$ and $\mathrm{H} 9), 9.76(d d, J=8.5,1.5 \mathrm{~Hz}$, $\mathrm{H} 3$ and H8) ppm. ${ }^{13} \mathrm{C}$ NMR (101 MHz, DMF- $\left.d_{7}\right): \delta=123.23$ ( $\mathrm{Cl}$ and C10), 125.73 (C1a and C10a), 132.80 (C5 and C6), 133.27 (C3 and C8),
147.10 (C4a and C6a), 152.60 (C2 and C9) ppm. $\mathbb{R}\left(\mathrm{KBr}, \nu, \mathrm{cm}^{-1}\right.$ ): $3094 \mathrm{w}, 2925 \mathrm{w}\left(\nu\left(\mathrm{C}_{\mathrm{ar}}-\mathrm{H}\right)\right), 1618 \mathrm{w}, 1584 \mathrm{w}, 1499 \mathrm{~s}, 1443 \mathrm{~m}\left(\nu\left(\mathrm{C}_{\mathrm{ar}}=\mathrm{C}_{\mathrm{ar}}\right)\right.$ and $\left.v\left(\mathrm{C}_{\mathrm{ar}}=\mathrm{N}\right)\right), 1115 \mathrm{vs}$ and $1059 \mathrm{~s}\left(v\left(\mathrm{ClO}_{4}\right)\right), 828 \mathrm{~m}, 796 \mathrm{~m}\left(\gamma\left(\mathrm{C}_{\mathrm{ar}}-\mathrm{H}\right)\right)$. UV-Vis (DMF/ $\left.\mathrm{H}_{2} \mathrm{O}, \lambda_{\max }, \mathrm{nm}\right): 272.0\left(\varepsilon=1.8 \cdot 10^{4} \mathrm{M}^{-1} \mathrm{~cm}^{-1}\right)$. ESI ${ }^{+}$. MS (DMF/ $\left.\mathrm{H}_{2} \mathrm{O}\right) \mathrm{m} / \mathrm{z}$ (relative intensity): $468.0\left[\mathrm{Ag}(4,7-\text { phen })_{2}\right]^{+}(100)$. $\Lambda_{\mathrm{M}}$ (DMSO): $31.3 \Omega^{-1} \mathrm{~cm}^{2} \mathrm{~mol}^{-1} ; \Lambda_{\mathrm{M}}$ (DMF): $70.4 \Omega^{-1} \mathrm{~cm}^{2} \mathrm{~mol}^{-1}$.

Anal. calcd for $\mathbf{4}=\mathrm{C}_{36} \mathrm{H}_{25.15} \mathrm{Ag}_{2} \mathrm{~F}_{12} \mathrm{~N}_{6} \mathrm{O}_{0.58} \mathrm{Sb}_{2}$ ( $\mathrm{MW}=1238.21$ ): $\mathrm{C}$, $34.89 ; \mathrm{H}, 2.05 ; \mathrm{N}, 6.78$. Found: $\mathrm{C}, 34.58 ; \mathrm{H}, 2.08 ; \mathrm{N}, 6.89 \% .{ }^{1} \mathrm{H}$ NMR (400 MHz, DMF- $\left.d_{7}\right): \delta=8.18(d d, J=8.4,4.5 \mathrm{~Hz}, \mathrm{H} 1$ and $\mathrm{H} 10), 8.68$ (s, $\mathrm{H} 5$ and $\mathrm{H} 6), 9.43$ (dd, $J=4.5,1.4 \mathrm{~Hz}, \mathrm{H} 2$ and $\mathrm{H} 9), 9.76(d d, J=8.5$, $1.3 \mathrm{~Hz}, \mathrm{H} 3$ and H8) ppm. $\left.{ }^{13} \mathrm{C} \mathrm{NMR} \mathrm{(101} \mathrm{MHz,} \mathrm{DMF-} d_{7}\right): \delta=123.25$ (C1 and $\mathrm{C} 10$ ), 125.72 (C1a and $\mathrm{C} 10 \mathrm{a}$ ), 132.65 (C5 and $\mathrm{C} 6$ ), 133.43 (C3 and C8), 146.93 (C4a and C6a), 152.36 (C2 and C9) ppm. IR ( $\mathrm{KBr}, \nu, \mathrm{cm}^{-1}$ ): $3434 \mathrm{br}(\nu(\mathrm{O}-\mathrm{H})), 2924 \mathrm{w}\left(\nu\left(\mathrm{C}_{\mathrm{ar}}-\mathrm{H}\right)\right), 1625 \mathrm{w}, 1588 \mathrm{~m}, 1526 \mathrm{~m}, 1502 \mathrm{~m}$, $1445 \mathrm{~m}\left(v\left(\mathrm{C}_{\mathrm{ar}}=\mathrm{C}_{\mathrm{ar}}\right)\right.$ and $\left.v\left(\mathrm{C}_{\mathrm{ar}}=\mathrm{N}\right)\right), 835 \mathrm{~m}, 797 \mathrm{~m}\left(\gamma\left(\mathrm{C}_{\mathrm{ar}}-\mathrm{H}\right)\right), 655 \mathrm{vs}$, 623vs $\left(\nu\left(\mathrm{SbF}_{6}\right)\right) . \quad \mathrm{UV}-\mathrm{Vis} \quad\left(\mathrm{DMF} / \mathrm{H}_{2} \mathrm{O}, \lambda_{\max }, \mathrm{nm}\right): 273.0$ $\left(\varepsilon=5.3 \cdot 10^{4} \mathrm{M}^{-1} \mathrm{~cm}^{-1}\right)$. ESI ${ }^{+}$-MS $\left(\mathrm{DMF} / \mathrm{H}_{2} \mathrm{O}\right) \mathrm{m} / \mathrm{z}$ (relative in$\begin{array}{lllll}\text { tensity): } \quad 468.0 \quad\left[\mathrm{Ag}(4,7-\mathrm{phen})_{2}\right]^{+} & (100) . & \Lambda_{\mathrm{M}} & \text { (DMSO): }\end{array}$ $68.5 \Omega^{-1} \mathrm{~cm}^{2} \mathrm{~mol}^{-1} ; \Lambda_{\mathrm{M}}$ (DMF): $160.6 \Omega^{-1} \mathrm{~cm}^{2} \mathrm{~mol}^{-1}$.

4,7-Phen data given for comparative purposes. $\mathrm{MW}=180.21$. ${ }^{1} \mathrm{H}$ NMR ( $\left.400 \mathrm{MHz}, \mathrm{DMF}-d_{7}\right): \delta=7.99(d d, J=8.4,4.3 \mathrm{~Hz}, \mathrm{H} 1$ and H10), 8.42 (s, H5 and H6), 9.26 (dd, $J=4.3,1.6 \mathrm{~Hz}, \mathrm{H} 2$ and $\mathrm{H} 9$ ), 9.55 (dd, $J=8.4,1.6 \mathrm{~Hz}, \mathrm{H} 3$ and H8) ppm. ${ }^{13} \mathrm{C}$ NMR $\left(101 \mathrm{MHz}, \mathrm{DMF}-d_{7}\right)$ : $\delta=122.48(\mathrm{C} 1$ and $\mathrm{C} 10), 125.23$ ( $\mathrm{Cla}$ and $\mathrm{C} 10 \mathrm{a}), 131.73$ (C3 and $\mathrm{C} 8$ ), 132.14 (C5 and C6), 147.80 (C4a and C6a), 151.01 (C2 and C9) ppm. IR $\left(\mathrm{KBr}, \nu, \mathrm{cm}^{-1}\right): 3065 \mathrm{w}, 3032 \mathrm{w}, 3003 \mathrm{w}, 2920 \mathrm{w}(\nu(\mathrm{Car}-\mathrm{H})), 1616 \mathrm{w}$,

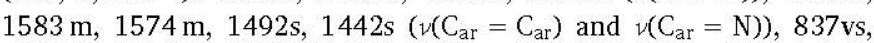
$791 \mathrm{vs}, 784 \mathrm{vs}(\gamma(\mathrm{Car}-\mathrm{H}))$. UV-Vis $\left(\mathrm{DMF} / \mathrm{H}_{2} \mathrm{O}, \lambda_{\max }, \mathrm{nm}\right): 272.0$ $\left(\varepsilon=2.0 \cdot 10^{4} \mathrm{M}^{-1} \mathrm{~cm}^{-1}\right)$.

\subsection{Air/light stability}

The air/light stability of $\mathbf{1 - 5}$ was studied in direct light in air atmosphere at room temperature. Sterile cellulose discs were impregnated with the corresponding silver(I) complex ( $5 \mu \mathrm{L}$ of $50 \mathrm{mg} / \mathrm{mL}$ DMSO stock solution) and exposed to air and light. The stability was monitored visually within $24 \mathrm{~h}$.

\subsection{Crystallogrophic data collection and refinement of the structures}

Crystal data and details of the structure determinations are listed in Table S1. A suitable crystal was selected, and the crystal was mounted on a mylar loop in oil on a STOE IPDS 2 diffractometer. The crystals were kept at 298(2) K for $\mathbf{1}$ and 3, 250(2) for 2 and 4, and 200(2) for 5 during data collection. Using Olex2 [19], the structure was solved with the ShelXT [20] structure solution program using Intrinsic Phasing and refined with the ShelXL [21] refinement package using Least Squares minimization. MERCURY computer graphics program [22] was used to prepare drawings.

\subsection{DNA binding study}

Spectrophotometric titrations were held by maintaining the concentration of the silver(I) complexes constant and varying ctDNA concentration (ct is calf thymus). The absorption spectra were recorded in the range $200-600 \mathrm{~nm}$. The baseline was corrected by subtracting that of Tris (tris(hydroxymethyl)aminomethane) buffer. Samples were incubated for 5 min prior measuring the spectra. From the UV-Vis titration data, the binding constants $\left(K_{b}\right)$ were calculated using the following equation [23]:

$[\mathrm{DNA}] /\left(\varepsilon_{\mathrm{a}}-\varepsilon_{\mathrm{f}}\right)=[\mathrm{DNA}] /\left(\varepsilon_{\mathrm{b}}-\varepsilon_{\mathrm{f}}\right)+1 / K_{b}\left(\varepsilon_{\mathrm{b}}-\varepsilon_{\mathrm{f}}\right)$

where $\varepsilon_{\mathrm{a}}, \varepsilon_{\mathrm{b}}$ and $\varepsilon_{\mathrm{f}}$ correspond to $\mathrm{A}_{\mathrm{obs}} /$ [complex], the extinction coefficients of the complexes in the bound and free forms, respectively. In plots of [DNA] $/\left(\varepsilon_{\mathrm{a}}-\varepsilon_{\mathrm{f}}\right)$ versus [DNA], $K_{b}$ is given by the ratio of the slope $\left(1 /\left(\varepsilon_{\mathrm{b}}-\varepsilon_{\mathrm{f}}\right)\right)$ to the intercept $\left(1 / K_{b}\left(\varepsilon_{\mathrm{b}}-\varepsilon_{\mathrm{f}}\right)\right)$. 
The competitive experiments were carried out in the buffer ( $\mathrm{pH} 7.4)$ by maintaining $[\mathrm{DNA}] /[\mathrm{EthBr}]=10$ (EthBr is ethidium bromide) and varying the concentration of the complexes $1-5$. Each sample solution was scanned in the wavelength range $525-800 \mathrm{~nm}$ with an excitation wavelength of $520 \mathrm{~nm}$. The Stern-Volmer constants $\left(K_{s v}\right)$, a measure of the binding propensity of the complexes to DNA, were calculated using the following equation [24]:

$$
\mathrm{F}_{0} / \mathrm{F}=1+K_{q} \boldsymbol{\tau}_{0}[\text { complex }]=1+K_{s v}[\text { complex }]
$$

where $\mathrm{F}_{0}$ and $\mathrm{F}$ stand for the fluorescence intensities in the absence and presence of the complexes, respectively. $K_{q}$ is bimolecular quenching constant and $\tau_{0}\left(10^{-8} \mathrm{~s}\right)$ is the life time of the fluorophore in the absence of the quencher. The binding constants $\left(K_{\mathrm{A}}\right)$ and apparent binding sites (n) can be analyzed by the following Eq. [24]:

$\log \left(\mathrm{F}_{0}-\mathrm{F}\right) / \mathrm{F}=\log K_{A}+\operatorname{nlog}$ [complex]

where $K_{A}$ is the binding constant of the silver(I) complex with $\mathrm{ctDNA}$, and $\mathrm{n}$ is the apparent number of binding sites. The plot of log $\left(\mathrm{F}_{0}-\mathrm{F}\right) / \mathrm{F}$ versus $\log [$ complex] was drawn and fitted linearly, from which slope $\mathrm{n}$ and value of binding constant $K_{A}$ can be obtained.

For the gel electrophoresis experiments, commercial lambda bacteriophage DNA (210 ng, Thermo Scientific ${ }^{\mathrm{ma}}$ ) was treated with complexes $1-5(400,40,10$ and $5 \mu \mathrm{M})$ in $30 \mu \mathrm{L}$ of water for $30 \mathrm{~min}$ at $37^{\circ} \mathrm{C}$. Control contained an appropriate volume of DMSO. After incubation, DNA samples were run, $175 \mathrm{ng}$ per lane, on a $0.8 \%(w / v)$ agarose gel containing $0.1 \mathrm{mg} / \mathrm{L}$ of ethidium bromide in TBE (Tris-borate-EDTA; EDTA is ethylenediaminetetraacetate) buffer (100 mM Tris, $90 \mathrm{mM}$ boric acid, 1 mM EDTA, pH 7.4), against a O'GeneRuler ${ }^{\text {Ts }} 1 \mathrm{~kb}$ Plus DNA Ladder (band sizes in bp: 75, 200, 350, 400, 500, 700, 1000, 1500, $2000,3000,4000,5000,7000,10,000,20,000$ ) (Thermo Scientific ${ }^{\text {тs }}$ ) at $50 \mathrm{~V}$ for $3 \mathrm{~h}$. Gels were visualized and analyzed using the Gel Doc EZ system (Bio-Rad, Life Sciences, Hercules, USA), equipped with the Image Lab ${ }^{\mathrm{TS}}$ software.

All cyclic voltammetric measurements were performed in a single compartment cell with a boron doped diamond electrode as a working electrode, $\mathrm{Ag} / \mathrm{AgCl}$ (saturated $\mathrm{KCl}$ ) as a reference electrode and a $\mathrm{Pt}$ wire as a counter electrode in DMSO and $0.1 \mathrm{M}$ tetrabutylammoniumhexafluorophosphate (TBAHP) as a supporting electrolyte. Potential was scanned in the range $-2.5-1.5 \mathrm{~V}$.

\subsection{Antimicrobial susceptibility testing}

Stock solutions of silver(I) complexes 1-5, 4,7-phenanthroline and silver(I) sulfadiazine (AgSD; Sigma, Munich, Germany) were prepared in DMSO (10 mM). All stock solutions were prepared fresh prior to use. The MICs against a panel of five microorganisms that included Escherichia coli NCTC 9001, Pseudomonas aeruginosa ATCC 27853, Klebsiella pneumoniae ATCC 13883, Staphylococcus aureus ATCC 25923 and Enterococcus faecalis ATCC 29212 (NCTC is National collection of type cultures and ATCC is American type culture collection), were determined in Luria-Bertani broth $(10 \mathrm{~g} / \mathrm{L}$ tryptone, $10 \mathrm{~g} / \mathrm{L} \mathrm{NaCl}, 5 \mathrm{~g} / \mathrm{L}$ yeast extract, $\mathrm{pH} 7.2$ ) in accordance with the standard broth microdilution assay for bacteria that grow aerobically, as recommended by the CLSI (Clinical and Laboratory Standards Institute 2015). The highest tested concentration of silver(I) complexes 1-5 was $500 \mu \mathrm{M}$ and the inocula were $1 \times 10^{6}$ colony forming units $(\mathrm{cfu}) / \mathrm{mL}$. Susceptibility testing of Candida spp. (C. albicans ATCC 10231, C. parapsilosis ATCC 22019, C. glabrata ATCC 2001, C. krusei ATCC 6258 and C. albicans SC5314 (ATCC MYA-2876)) was performed according to the CLSI broth microdilution guidelines (Clinical and Laboratory Standards Institute 2008; Clinical and Laboratory Standards Institute 2012), in RPMI 1640 medium (Sigma-Aldrich, Munich, Germany) with $2 \%$ of glucose. The highest tested concentration of silver(I) complexes 1-5 was $500 \mu \mathrm{M}$, and the inocula were $1 \times 10^{5} \mathrm{cfu} / \mathrm{mL}$. MIC values were determined after $24 \mathrm{~h}$ of incubation at $37^{\circ} \mathrm{C}$ as the lowest concentration to cause the absence of growth.

\subsection{In vitro cytotoxicity}

Antiproliferative activities of silver(I) complexes 1-5, 4,7-phenanthroline and silver(I) sulfadiazine were measured using the standard colorimetric MTT (3-(4,5-dimethylthiazol-2-yl)-2,5-diphenyltetrazolium bromide) assay [25]. MRC-5 cells (human lung fibroblast obtained from ATCC) were plated in a 96-well flat-bottom plate at a concentration of $1 \times 10^{4}$ cells per well, grown in humidified atmosphere of $95 \%$ air and $5 \% \mathrm{CO}_{2}$ at $37{ }^{\circ} \mathrm{C}$ and maintained as monolayer cultures in RPMI 1640 medium (Gibco). Each tested compound was added to the cells at a concentration ranging from 5 to $200 \mu \mathrm{M}$ and the treatment lasted for $48 \mathrm{~h}$. The MTT assay was performed two times in four replicates and the extent of MTT reduction was measured spectrophotometrically at $540 \mathrm{~nm}$ using a Tecan Infinite 200 Pro multiplate reader (Tecan Group Ltd., Mannedorf, Switzerland). Cytotoxicity was expressed as the concentration of the compound inhibiting cell growth by $50 \%\left(\mathrm{IC}_{50}\right)$ in comparison to control (DMSO-treated cells).

\subsection{The effect on C. albicans yeast to hyphae transition}

Morphological changes of $C$. albicans in the presence and absence of 4,7-phenanthroline, nystatin, AgSD, and silver(I) complexes 1-5, at the sub-inhibitory concentrations $(0.7 \times$ MIC; $70 \%$ of MIC value determined for the planktonic growth) was observed upon $C$. albicans growth on Spider medium as previously described [26].

\subsection{ROS production in Candida albicans}

Intracellular reactive oxygen species (ROS) were measured using the fluorescent dye $2^{\prime}, 7^{\prime}$-dichlorofluorescin diacetate (DCFH-DA, Sigma) as previously described [27] with some modifications. Briefly, freshly grown $C$. albicans cells were inoculated into Sabouraud dextrose broth and grown until $\mathrm{OD}_{530}=0.15$ (approximately $4 \times 10^{6}$ cells per $\mathrm{mL}$ ). C. albicans cells in aliquots of $5 \mathrm{~mL}$ were further incubated with $1 \times$ MIC concentrations of silver(I) complexes 1-5. After incubation, the cells were collected, washed with PBS and stained with $10 \mu \mathrm{M}$ DCFH-DA at $30^{\circ} \mathrm{C}$ for $30 \mathrm{~min}$. Finally, the cells were collected, washed with PBS (phosphate buffered saline) once more and analyzed. The fluorescence intensities (excitation and emission of 488 and $540 \mathrm{~nm}$, respectively) of cells were determined by CyFlow Space Partec flow cytometer with Partec FloMax software (Partec GmbH, Munster, Germany).

\subsection{Toxicity assessment using zebrafish}

Evaluation of toxicity of silver(I)-4,7-phenanthroline complexes in the zebrafish model was carried out according to general rules of the OECD Guidelines for the Testing of Chemicals (OECD is Organisation for Economic Co-operation and Development) [28]. All experiments involving zebrafish were performed in compliance with the European directive 2010/63/EU and the ethical guidelines of the Guide for Care and Use of Laboratory Animals of the Institute of Molecular Genetics and Genetic Engineering, University of Belgrade.

Embryos of wild type zebrafish (Danio rerio) were kindly provided by Dr. Ana Cvejic (Wellcome Trust Sanger Institute, Cambridge, UK), raised to adult stage in a temperature- and light-controlled zebrafish facility with $28^{\circ} \mathrm{C}$ and standard 14:10-h light-dark photoperiod and regularly fed with commercially dry flake food (TetraMin ${ }^{\text {Tx }}$ flakes; Tetra Melle, Germany) twice a day and Artemia nauplii once daily. Zebrafish embryos were produced by pair-wise mating, collected and distributed into 24-well plates containing 10 embryos per well and $1 \mathrm{~mL}$ embryos water $\left(0.2 \mathrm{~g} / \mathrm{L}\right.$ of Instant Ocean ${ }^{\circledast}$ Salt in distilled water) and raised at $28^{\circ} \mathrm{C}$. For assessing lethality, developmental toxicity and cardiotoxicity, the embryos staged at $38 \mathrm{~h}$ post fertilization (hpf) (corresponding to the time when heart is formed, and the embryos used for infection experiments with $C$. albicans were treated with antifungal complexes) 
were exposed to different concentrations of each of the tested complexes. DMSO $(0.25 \%)$ was used as negative control. Experiments were performed three times using 30 embryos per concentration.

Apical endpoints for the toxicity evaluation (Table S2) were recorded at 48, 72, 96 and 120 hpf using an inverted microscope (CKX41; Olympus, Tokyo, Japan). Dead embryos were counted and discarded every $24 \mathrm{~h}$. At $120 \mathrm{hpf}$, embryos were inspected for heartbeat rate, anesthetized by addition of $0.1 \%(\mathrm{w} / \mathrm{v})$ tricaine solution (SigmaAldrich, St. Louis, MO), photographed and killed by freezing at $-20^{\circ} \mathrm{C}$ for $\geq 24 \mathrm{~h}$.

\subsection{Myelotoxicity evaluation in the zebrafish model}

In order to address a possible myelosuppressive activity of the selected silver(I) complexes with 4,7-phenathroline (1, 3 and 5), transgenic $T g(m p x: E G F P)$ zebrafish embryos with fluorescently labeled neutrophils were used, enabling direct visualization of the applied therapy on the occurrence of neutrophils within the developing embryos. Transgenic embryos were generated by natural spawning of $T g$ (mpx:EGFP) and wild type adults, and reared in the fish embryo water at $28^{\circ} \mathrm{C}$. At the $38 \mathrm{hpf}$ stage (when neutrophils are differentiated and phagocytically active), embryos were exposed to different doses $(1 / 2 \times$ MIC, $1 \times$ MIC and $2 \times$ MIC) of the tested complexes and inspected at $120 \mathrm{hpf}$ stage under a fluorescence microscope (Olympus BX51, Applied Imaging Corp., San Jose, CA, USA) for the presence of neutrophils and fluorescence intensity. The occurrence of neutrophils (fluorescence) was determined by ImageJ programme (NIH public domain software; NIH is National Institutes of Health).

\subsection{The zebrafish infection}

In order to evaluate antifungal efficacy of the most active complexes 1,3 and 5 in vivo, we employed the zebrafish model of lethal disseminated candidiasis, following the previously established procedure $[29,30]$. The antifungal efficacy was evaluated according to the infected embryos survival and the fungal burden at 2 and 4 days post infection (dpi).

2.13.1. C. abicans culture and preparation of the cells for microminection The GFP (green fluorescent protein) expressing strain M137 of $C$. albicans CS5314 (provided by Marina Pekmezovic, Department of - Microbial Pathogenicity Mechanisms, Hans Knöll Institute, Jena, Germany) were used for the infection experiments. To obtain log-phase cells for injection, the single colonies of M137 strain from YPD (yeast extract peptone dextrose) plates were inoculated in liquid YPD medum, grown overnight at $37^{\circ} \mathrm{C}$ with shaking ( $180 \mathrm{rpm}$ ), subcultured 1: 100 in the same medium and grown to an optical density $\left(\mathrm{A} 530_{\mathrm{nm}}\right)$ of $\sim$ 0.7-0.8. To prepare final inoculum for microinjection, $2 \mathrm{~mL}$ of the $\log$ phase cells was pelleted by a centrifugation ( $1500 \mathrm{~g}$ for $10 \mathrm{~min}$ ) (Centrifuge 5415D, Eppendorf, Hamburg, Germany), washed three times with sterile $1 \times \mathrm{PBS}$, and finally suspended in $5 \%$ polyvinylpyrrolidone (PVP) to achieve a final concentration of $2 \times 10^{7}$ cells $/ \mathrm{mL}$.

\subsubsection{Infection of zebrafish embryos}

The infection experiments were performed using wild type zebrafish embryo generated on the previously described manner. At $24 \mathrm{hpf}$, embryos were manually dechorionated, and kept in the embryos water at $28.5^{\circ} \mathrm{C}$. At $32-33 \mathrm{hpf}$, embryos were anesthetized by addition of tricaine-methane sulfonate $(200 \mu \mathrm{g} / \mathrm{mL})$, and microinjected by a pneumatic picopump (PV820, World Precision Instruments, USA) with $\sim 5 \mathrm{~nL}$ of $C$. abicans M137 cells suspension at $2 \times 10^{7}$ cells $/ \mathrm{mL}$ in $5 \%$ PVP through the otic vesicle into the hindbrain to achieve a dose of
40-70 fungal cells. The injected embryos were kept at $30^{\circ} \mathrm{C}$ and at $2 \mathrm{~h}$ post infection were treated with different doses $(1 / 2 \times$ MIC, $1 \times$ MIC and $2 \times$ MIC) of each of the selected complexes. The embryos injected with only $5 \%$ PVP were used as the control group. The survival of infected fish was monitored at regular intervals up to 4 dpi under a stereomicroscope (SMZ143-N2GG, Motic, Germany). Dead fish were removed daily.

\subsubsection{Enumeration of fungal burdens}

Individual fish that were alive at 2 and 4 dpi were homogenized in Eppendorf tubes containing $200 \mu \mathrm{L} 1 \times$ PBS supplemented with nalidixic acid $(70 \mu \mathrm{g} / \mathrm{mL})$ and ampicillin $(100 \mu \mathrm{g} / \mathrm{mL})$ by using a sample pestle. Serial dilution was made in $1 \times$ PBS with antibiotics and plated on YPD medium. Plates were incubated at $37^{\circ} \mathrm{C}$ for 3 days prior to counting.

\section{Results and discussion}

\subsection{Synthesis and structural elucidation of the silver(I) complexes 1-5}

The silver(I) complexes with 4,7-phenanthroline (4,7-phen) were synthesized according to the approach presented in Scheme 1 . The reactions between $\mathrm{AgX}\left(\mathrm{X}=\mathrm{NO}_{3}^{-}, \mathrm{CF}_{3} \mathrm{COO}^{-}\right.$and $\left.\mathrm{BF}_{4}{ }^{-}\right)$and 4,7-phen in a 2: 1 molar ratio were conducted in methanol/acetone $(\mathrm{v} / \mathrm{v} 1: 1)$ at room temperature yielding the target polynuclear $\left[\mathrm{Ag}\left(\mathrm{NO}_{3}-\mathrm{O}\right)(4,7-\right.$ phen- $\mu-N 4, N 7)]_{\mathrm{n}}(1), \quad\left[\mathrm{Ag}\left(\mathrm{CF}_{3} \mathrm{COO}-O\right)(4,7-\text { phen- } \mu-N 4, N 7)\right]_{\mathrm{n}}$ (3) and $\left\{\left[\mathrm{Ag}_{2}\left(\mathrm{H}_{2} \mathrm{O}\right)(4,7 \text {-phen- } \mu-N 4, N 7)_{2}\right]\left(\mathrm{BF}_{4}\right)_{2}\right\}_{\mathrm{n}}(5)$ complexes. On the other hand, the reactions of $\mathrm{AgClO}_{4}$ and $\mathrm{AgSbF}_{6}$, and 4,7-phen were performed by mixing equimolar amounts in ethanol at room temperature leading to the formation of polynuclear $\left[\mathrm{Ag}\left(\mathrm{ClO}_{4}-\mathrm{O}\right)(4,7-\right.$ phen- $\mu$ $N 4, N 7)]_{\mathrm{n}}$ (2) and dinuclear $\left[\mathrm{Ag}_{2}\left(\mathrm{H}_{2} \mathrm{O}\right)_{0.58}(4,7-\mathrm{phen})_{3}\right]\left(\mathrm{SbF}_{6}\right)_{2}$ (4) complexes. In all these complexes, 4,7-phen is a bridging ligand between two $\mathrm{Ag}(\mathrm{I})$ ions. In complexes 1-3, which were formed in the reactions of silver(I) salts having oxygen-containing counterions, the corresponding anion $\left(\mathrm{NO}_{3}{ }^{-}, \mathrm{ClO}_{4}^{-}\right.$and $\left.\mathrm{CF}_{3} \mathrm{COO}^{-}\right)$is coordinated to the $\mathrm{Ag}(\mathrm{I})$ ion; $\mathrm{NO}_{3}{ }^{-}$and $\mathrm{ClO}_{4}{ }^{-}$are coordinated monodentately, while $\mathrm{CF}_{3} \mathrm{COO}^{-}$acts as a bridging ligand between $\mathrm{Ag}(\mathrm{I})$ ions. On the contrary, no coordination of fluorine-containing anions $\left(\mathrm{SbF}_{6}{ }^{-}\right.$and $\left.\mathrm{BF}_{4}{ }^{-}\right)$to the $\mathrm{Ag}(\mathrm{I})$ ion was observed in complexes 4 and 5 , respectively. However, these two complexes contain coordinated water molecules, being in accordance with previous findings, where the ability of solvent to coordinate $\operatorname{Ag}(\mathrm{I})$ ion is inversely proportional to the order of the coordination ability of the polyatomic anions [31]. Thus, the coordinating nature of oxygen-containing anions represents an obstacle to the solvent coordination, while weakly coordinating $\mathrm{SbF}_{6}{ }^{-}$and $\mathrm{BF}_{4}{ }^{-}$anions afford water-containing complexes 4 and 5 . The bond valence sums (BVS) for each $\mathrm{Ag}(\mathrm{I})$ ion in $\mathbf{1 - 5}$ are summarized in Table S3.

The molar conductivity measurements were performed in order to check the electrolytic nature of the complexes 1-5 in DMSO solution (a solvent used for the preparation of stock solution for biological evaluation of the complexes) and in DMF (a solvent used for spectral characterization). Based on these measurements we have found that a release of coordinated $\mathrm{NO}_{3}{ }^{-}$anion in complex $1, \mathrm{ClO}_{4}{ }^{-}$in complex 2 and $\mathrm{CF}_{3} \mathrm{COO}^{-}$in complex 3 occurred after dissolution of these complexes in DMSO and DMF solvents. The molar conductivity measured immediately after dissolution of these complexes did not change significantly during $48 \mathrm{~h}$. By comparison of the obtained data for complexes 1-3 with those previously reported for different compounds dissolved in the same solvents [32,33], it can be concluded that these complexes behave as 1:1 type of electrolyte. However, complexes 4 and 5 , with fluorine-containing counter-anions, showed the molar conductivities that are in accordance with 1:2 type of electrolyte [32,33]. 

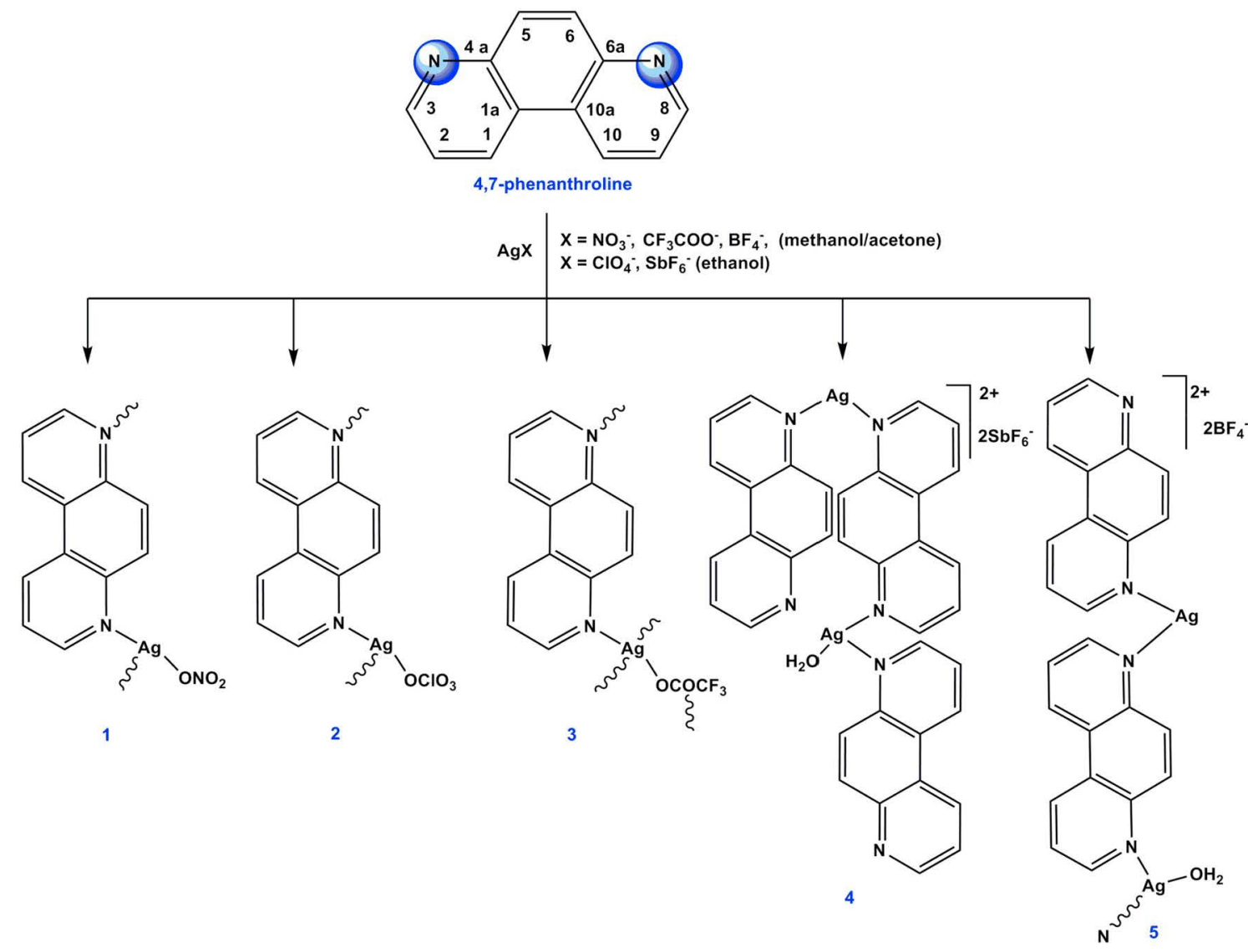

Scheme 1. Schematic presentation of the synthesis of silver(I) complexes 1-5. Numeration of carbon atoms in 4,7-phen is in accordance with IUPAC recommendations for fused ring systems and does not match the one applied in the X-ray study of silver(I) complexes.

\subsubsection{Description of the single crystal structures}

The molecular structures of silver(I) complexes 1-5 with the anisotropic displacement ellipsoids and the atom numbering scheme are shown in Fig. 1. The relevant bond distances $(\AA)$ and angles $\left({ }^{\circ}\right)$ with the estimated standard deviations are summarized in Table S3.

Complexes 1 and 2 have polymeric structures, which comprise 4,7phen-bridged $\mathrm{Ag}_{2}\left(\mathrm{NO}_{3}\right)_{2}$ and $\mathrm{Ag}_{2}\left(\mathrm{ClO}_{4}\right)_{2}$ subunits (Fig. 1). The $\mathrm{Ag}(\mathrm{I})$ ion in these complexes adopts a distorted trigonal planar geometry, with $\mathrm{N} 1-\mathrm{Ag}-\mathrm{N} 2, \quad \mathrm{~N} 1-\mathrm{Ag}-\mathrm{O} 3 / \mathrm{O} 1$ and $\mathrm{N} 2-\mathrm{Ag}-\mathrm{O} 3 / \mathrm{O} 1$ angles of $139.34(1) / 150.98(9), 113.16(1) / 86.10(9)$ and $92.34(1) / 110.70(9)^{\circ}$, respectively (Table S3). On the other hand, complex 3 has a strongly distorted tetrahedral geometry around the $\mathrm{Ag}(\mathrm{I})$ ion, as can be deduced from the value of $\tau_{4}$ parameter [34] of $0.64, \tau_{4}=\left[360^{\circ}-(\beta+\alpha)\right] /$ $141^{\circ}$, where $\beta$ and $\alpha$ are the largest angles around the metal ion. Each $\mathrm{Ag}(\mathrm{I})$ ion is surrounded by two 4,7-phen and two trifluoroacetate anions. Two $\mathrm{Ag}(\mathrm{I})$ ions are connected by one 4,7-phen and one $\mathrm{CF}_{3} \mathrm{COO}^{-}$, which behave as a bridging ligand (crystal packing is shown in Fig. S1). The $\mathrm{Ag}-\mathrm{N}(4,7-$ phen) bond lengths fall in the range of 2.193(2) $-2.274(3) \AA$ and compare well with those observed in the other silver(I) complexes with aromatic $N$-heterocycles $[14,17,35-40]$. On the other hand, the average $\mathrm{Ag}-\mathrm{O}$ bond distance of $2.548 \AA$ is much longer than a usual covalent silver(I)-oxygen bonds of approximately $2.3 \AA$ [35].

Complexes 4 and 5 obtained in the reactions of 4,7-phen with silver (I) salts having fluorine-containing counterions are dinuclear and polynuclear species, respectively (Fig. 1). In these compounds, there are two independent $\mathrm{Ag}(\mathrm{I})$ metal ions ( $\mathrm{Ag} 1$ and $\mathrm{Ag} 2$ ), which have different geometry. The Ag1 ion is coordinated by two nitrogen atoms of two 4,7phen, leading to its distorted linear geometry with an angle of $175.5(4)$ and $165.01(8)^{\circ}$, respectively. The Ag2 ion has a distorted trigonal planar geometry as a consequence of coordination of two 4,7-phen ligands and water in the third coordination site, although in 4 , the position of the water is occupied at $58(4) \%$. The water molecule is more strongly coordinated to $\mathrm{Ag} 2$ in $\mathbf{4}$ in respect to $\mathbf{5}$, as deduced from the $\mathrm{Ag}-\mathrm{O}$ bond lengths (2.43(2) $\AA$ in 4 and 2.631(2) $\AA$ in 5, Table S3). This difference in $\mathrm{Ag}-\mathrm{O}$ bond lengths can be attributed to the fact that the $\mathrm{O} 1$ oxygen atom in complex 5 is the donor of hydrogen bond, in which fluorine of $\mathrm{BF}_{4}{ }^{-}$acts as an acceptor (Table S4). On the other hand, the coordinated $\mathrm{O} 1$ oxygen atom in 4 is engaged in intermolecular hydrogen bonding with non-coordinated N1 nitrogen of 4,7-phen (Table S4).

The IR, NMR $\left({ }^{1} \mathrm{H}\right.$ and $\left.{ }^{13} \mathrm{C}\right)$ and UV-Vis spectroscopic data for 4,7phen and silver(I) complexes 1-5 are listed in the Experimental section. The IR spectra of complexes, recorded in the wavenumber range of $4000-450 \mathrm{~cm}^{-1}$, are consistent with the structures determined by X-ray diffraction analysis and show the bands attributable to the vibration of the coordinated 4,7-phen, as well as those due to the coordinated oxygen-containing anions in 1-3 [41-46] and fluorine-containing counter-anions in 4 and 5 [47-49].

Both ${ }^{1} \mathrm{H}$ and ${ }^{13} \mathrm{C}$ spectra of the complexes 1-5 are consistent with a presence of symmetric species in solution and contain the same number of signals as those for the uncoordinated 4,7-phen. This indicates that both $\mathrm{N} 4$ and $\mathrm{N} 7$ nitrogen atoms are coordinated to $\mathrm{Ag}(\mathrm{I})$, i.e. 4,7-phen acts as a bridging ligand between two $\mathrm{Ag}(\mathrm{I})$ ions, but also might mean that the compounds undergo rapid dynamic processes in solution, which may include equilibria between species/oligomers of different nuclearities [50]. The resonances for the protons in 1-5 are shifted downfield with respect to those in uncoordinated 4,7-phen. On the other hand, in the ${ }^{13} \mathrm{C}$ NMR spectra of all complexes, the nitrogen-adjacent $\mathrm{C}$-atoms, i.e. $\mathrm{C} 4 \mathrm{a} / \mathrm{C} 6 \mathrm{a}$ were shielded (up to $-0.87 \mathrm{ppm}$ in 4 ), while the other ring carbons were deshielded (up to $+1.70 \mathrm{ppm}$ for $\mathrm{C} 3$ / C8 in 4). 


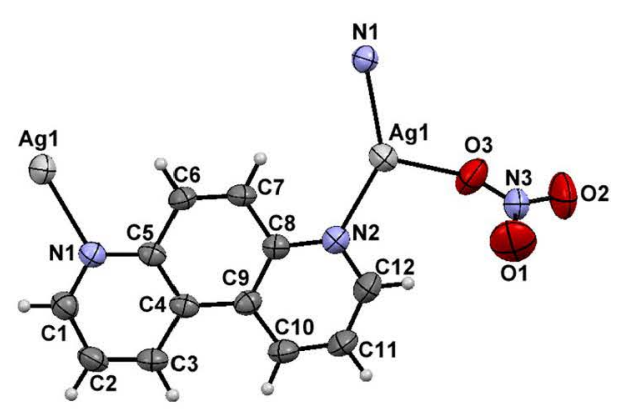

1

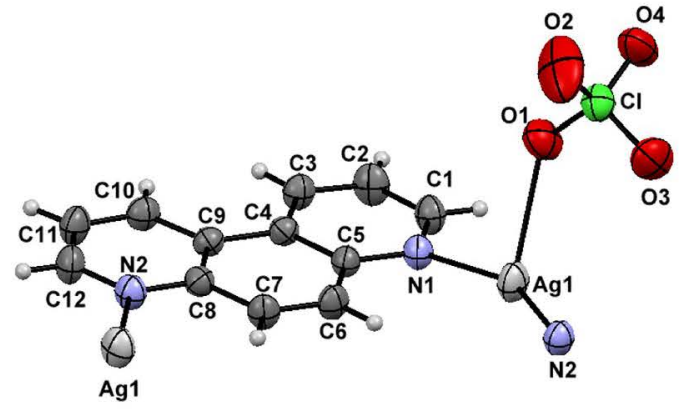

2
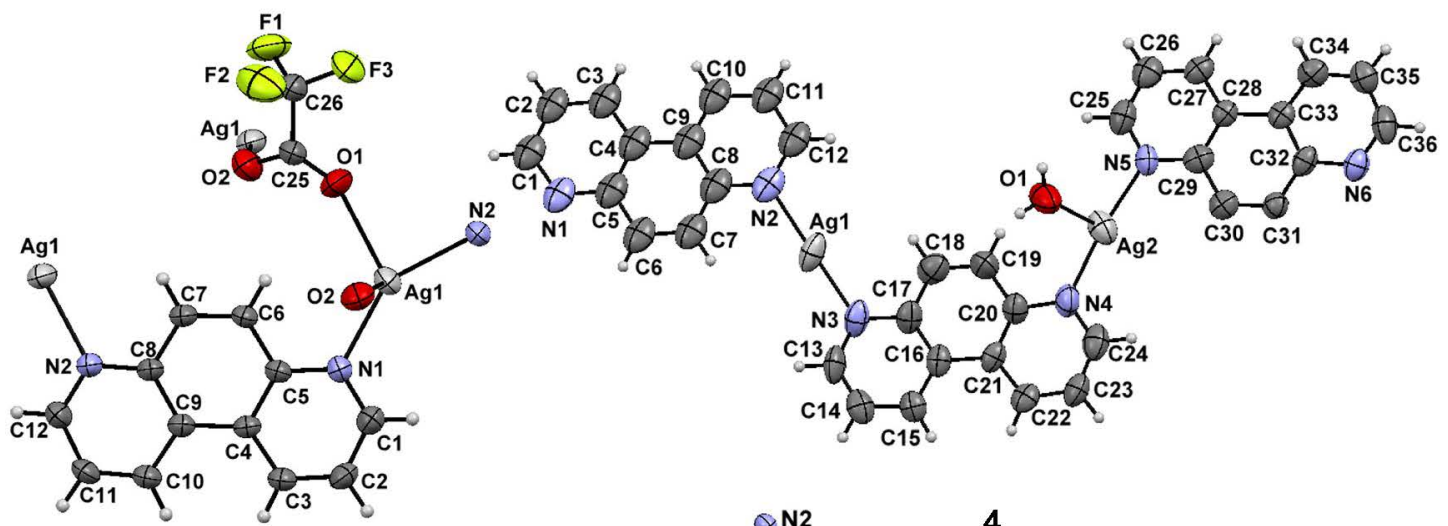

3

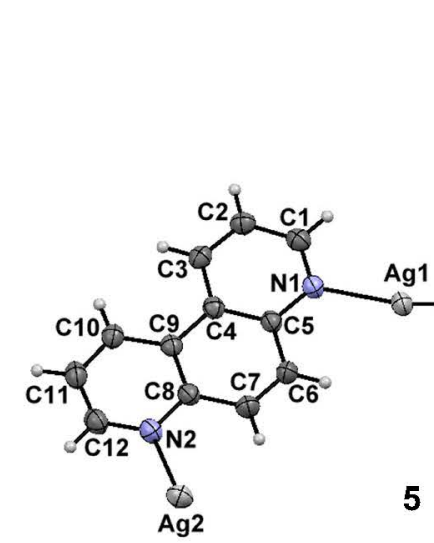

Fig. 1. Molecular structures of the silver(I) complexes 1-5. Non-coordinating $\mathrm{SbF}_{6}{ }^{-}$and $\mathrm{BF}_{4}{ }^{-}$anions in 4 and $\mathbf{5}$, respectively, are omitted for clarity. Displacement ellipsoids are drawn at $50 \%$ probability level and $\mathrm{H}$ atoms are represented by spheres of arbitrary size.

The UV-Vis spectra of silver(I) complexes 1-5 and 4,7-phen, were recorded in DMF/ $\mathrm{H}_{2} \mathrm{O}$ at room temperature. The absorbance peaks at 272.0 for $1-3$ and 5 , and $273.0 \mathrm{~nm}$ for 4 are due to the characteristic $\pi \rightarrow \pi^{*}$ transitions in the $N$-heterocyclic ligand [51,52]. Only the absorbance peak for 4 is slightly batochromic shifted with respect to that for the uncoordinated 4,7-phen $(\lambda=272.0 \mathrm{~nm})$.

In the mass spectra of complexes $1-5$, the major doublet peak is the one centered at $\mathrm{m} / \mathrm{z}$ (relative intensity) $=468.0$ (100), which can be assigned to $\left[\mathrm{Ag}(4,7-\text { phen })_{2}\right]^{+}$cation.

\subsubsection{Electrochemical behavior}

Electrochemical behavior of the silver(I) complexes was monitored using cyclic voltammetry in DMSO and $0.1 \mathrm{M}$ tetrabutylammoniumhexafluorophosphate (TBAHP) as a supporting electrolyte. The potential was scanned from -2.5 to $1.5 \mathrm{~V}$. The cyclic voltammograms recorded for the complexes are presented in Fig. 2. As can be seen, in anodic direction, one well-defined oxidation peak was observed. On the other hand, in the reverse scan, three peaks were noticed for all complexes. Redox pair $\mathrm{I}_{\mathrm{a}}$ and $\mathrm{I}_{\mathrm{c} 1}$ can be attributed to the

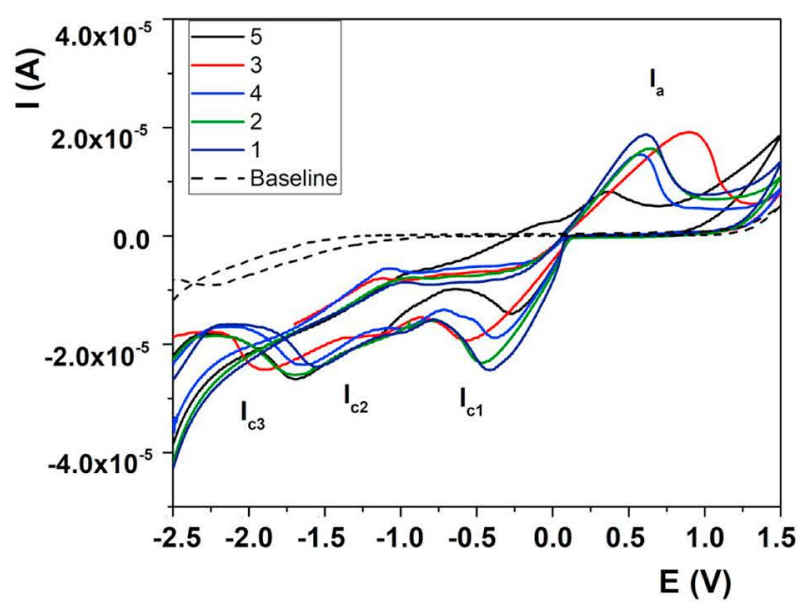

Fig. 2. Electrochemical behavior of the silver(I) complexes 1-5. Cyclic voltammograms were recorded at BDD electrode, in DMSO and 0.1 M TBAHP as a supporting electrolyte with a scan rate of $50 \mathrm{mV} / \mathrm{s}$. 
quasi-reversible redox reaction of silver(I) ion. The potentials of these peaks are dependent on the complex structure. The highest potential values are observed for complex 3 having distorted tetrahedral geometry in the solid state, while the lowest one are due to the complex 5 having a linear and a trigonal-planar $\mathrm{Ag}(\mathrm{I})$ metal ions (Fig. 1). Nevertheless, the half potential for all complexes were $\sim 0.1-0.2 \mathrm{~V}$, corresponding to the characteristic potential for $\mathrm{Ag}(\mathrm{I})$ [53]. The second oxidation peak $\left(\mathrm{I}_{\mathrm{c} 2}\right)$ can be attributed to the reduction of 4,7-phenanthroline moiety, while the third reduction peak $\left(\mathrm{I}_{c 3}\right)$ is due to the reduction of both moieties, silver(I) ion and 4,7-phen [53,54].

\subsection{Stability of complexes $1-5$}

The solution behavior of $\mathrm{Ag}(\mathrm{I})$ complexes 1-5 was analyzed in DMSO- $d_{6}$ (solvent used for biological evaluation) by NMR spectroscopy. The ${ }^{1} \mathrm{H}$ NMR spectra were recorded after dissolution of the complexes and after $24 \mathrm{~h}$ standing of these solutions in the dark at room temperature (Fig. S2; for complex 4). For all complexes, no release of 4,7phen and no coordination of the solvent to $\mathrm{Ag}(\mathrm{I})$ ion were observed, implying their substantial stability in solution during that time. Moreover, the stability of the complexes was checked by UV-Vis spectrophotometry (Fig. S3). For this purpose, they were dissolved in DMF/RPMI medium with $2 \%$ of glucose (v/v 1:9) at room temperature, and the resulting solutions were monitored by measuring the UV-Vis spectra over $24 \mathrm{~h}$ at room temperature. No change in the intensity and the position of the absorption maxima for the investigated complexes was observed during this time. More specifically, the shape of the spectra remained unmodified, implying the stability of the complexes in DMF/RPMI medium.

In order to investigate the air/light stability of the silver(I) complexes, sterile cellulose discs impregnated with these complexes $(5 \mu \mathrm{L}$ of $50 \mathrm{mg} / \mathrm{mL}$ DMSO stock solution) were exposed to air and light for $24 \mathrm{~h}$ (Fig. S4). All investigated silver(I) compounds started becoming darker in color, indicating that a slow light decomposition processes occurred during the investigated time which was slower for $\mathbf{1}$ and $\mathbf{3}$ in comparison to the other three complexes.

\subsection{Antimicrobial activity and antiproliferative effect of 1-5}

The antimicrobial activity of the silver(I) complexes 1-5 was compared with that of 4,7-phen and silver(I) sulfadiazine (AgSD), the most widely used antimicrobial agent based on the silver(I) [55,56]. MIC values against the investigated bacterial strains for complexes 1-5 were found to be in the range between 8.1 and $258.1 \mu \mathrm{M}$ (Table 1). They showed considerably higher antibacterial activity compared to the 4,7phen, while their MIC values in comparison to that of AgSD were in most cases either higher or comparable, indicating that they have moderate antibacterial activity. An exception was the polynuclear complex 5 which contains $\mathrm{BF}_{4}{ }^{-}$as a counterion, that showed MIC value against Gram-negative Escherichia coli between 2.5- and 8-fold diminished as opposed to the other tested Ag(I) complexes, and 6.2-fold lower in comparison to that of AgSD (Table 1). The influence of a counter anion on the biological activity of $\mathrm{Ag}(\mathrm{I})$ complexes was also observed for silver(I)-metronidazole complexes containing $\mathrm{BF}_{4}{ }^{-}$and $\mathrm{ClO}_{4}{ }^{-}$anions, which were found to be very effective against the tested Gramnegative bacteria [45]. The antibacterial activity of complexes 1-5 was better than that shown by $\mathrm{Ag}(\mathrm{I})$ complexes containing 1,10- and 1,7phenanthroline, which are isomeric to the presently used ligand [13-16].

From the obtained results it is not clear whether the $\mathrm{Ag}(\mathrm{I})$ complexes were more active against Gram-positive or Gram-negative bacteria; however, they exhibited a significantly higher activity against the tested Candida strains with the MIC values being in the range from 2.0 to $25.0 \mu \mathrm{M}$ (Table 1). Among the investigated strains, two C. albicans strains were the most sensitive, while the complex 5 exhibited the highest activity. Complex 1 also showed high anti-Candida activity,
Table 1

Antimicrobial activity of $\mathrm{Ag}(\mathrm{I})$ complexes 1-5, 4,7-phen and silver(I) sulfadiazine AgSD (MIC, $\mu \mathrm{M}$ ), in comparison to their antiproliferative effect on normal human fibroblast cell line MRC-5 $\left(\mathrm{IC}_{50}, \mu \mathrm{M}\right)$.

\begin{tabular}{|c|c|c|c|c|c|c|c|}
\hline Compound & 1 & 2 & 3 & 4 & 5 & 4,7-Phen & $\mathrm{AgSD}$ \\
\hline \multicolumn{8}{|l|}{ Test organism } \\
\hline $\begin{array}{l}\text { E. coli } \\
\qquad \text { NCTC } 9001\end{array}$ & $47.1^{\mathrm{a}}$ & 64.5 & 62.3 & 20.1 & 8.1 & 500 & 50 \\
\hline $\begin{array}{l}\text { P. aeruginosa } \\
\text { ATCC } 27853\end{array}$ & 50.2 & 64.5 & 249.3 & 160.5 & 130.2 & 500 & 25 \\
\hline $\begin{array}{l}\text { K. pneumoniae } \\
\text { ATCC } 13883\end{array}$ & 95.2 & 258.1 & 249.3 & 80.3 & 130.2 & 500 & 75 \\
\hline $\begin{array}{l}\text { S. aureus } \\
\quad \text { ATCC } 25923\end{array}$ & 95.2 & 65.5 & 62.3 & 40.1 & 32.6 & 500 & 75 \\
\hline $\begin{array}{l}\text { E. faecalis } \\
\text { ATCC } 29212\end{array}$ & 95.2 & 32.3 & 62.3 & 20.1 & 32.6 & 500 & 100 \\
\hline $\begin{array}{l}\text { C. albicans } \\
\quad \text { ATCC } 10231\end{array}$ & 10 & 8 & 3.9 & 5 & 2 & 500 & 10 \\
\hline $\begin{array}{l}\text { C. albicans CS5314 } \\
\text { ATCC MYA-2876 }\end{array}$ & 6.2 & 6.2 & 3.1 & 3.1 & 3.1 & 500 & 6.2 \\
\hline $\begin{array}{l}\text { C. parapsilosis } \\
\quad \text { ATCC } 22019\end{array}$ & 2.5 & 8 & 7.8 & 25 & 8.1 & 500 & 2.5 \\
\hline $\begin{array}{l}\text { C. glabrata } \\
\text { ATCC } 2001\end{array}$ & 15 & 8 & 15 & 10 & 8.1 & 600 & 5.1 \\
\hline $\begin{array}{l}\text { C. krusei } \\
\text { ATCC } 6258\end{array}$ & 2.5 & 8.1 & 7.8 & 2.5 & 4.1 & 500 & 2.5 \\
\hline MRC-5 cells & $35^{\mathrm{b}}$ & 15 & 17 & 5 & 10 & 70 & 10 \\
\hline
\end{tabular}

${ }^{a}$ Results are given as mean of three independent measurements with standard error being between $1-3 \%$.

${ }^{b}$ Calculated IC $\mathrm{S}_{50}$ values correspond to the concentrations required to inhibit $50 \%$ of the cell growth.

while its cytotoxic effect was the lowest among the tested silver(I) complexes. Generally, the cytotoxic activity of the silver(I) complexes discussed here was moderate and, in most cases, lower than that of $\mathrm{AgSD}$ and therefore prompted further studies of these compounds as possible antifungal agents.

The preference of silver(I) complexes towards Candida strains in comparison to the bacterial strains was also previously found for $\mathrm{Ag}(\mathrm{I})$ complexes with 1,7-phenanthroline, with $\left[\mathrm{Ag}\left(\mathrm{NO}_{3}-\mathrm{O}, \mathrm{O}^{\prime}\right)(1,7\right.$-phen$N 7)_{2}$ ] being the most active [14], highlighting the critical role of the ligands for the biological activity of the $\mathrm{Ag}(\mathrm{I})$ complexes. A similar outcome was observed for the $\operatorname{Ag}(\mathrm{I})$ complexes with 2-amino-3-methylpyridine, pyridine-2-carboxaldoxime and substituted imidazoles which exhibited significant activity against $C$. albicans, whereas their antibacterial activity was quite moderate $[57,58]$. On the contrary, $\mathrm{Ag}$ (I) complexes with heterocycles containing two nitrogen atoms within one ring, such as diazines (pyridazine, pyrimidine, pyrazine), benzodiazines (phthalazine, quinazoline, quinoxaline) and tricyclic phenazine, showed the remarkable antibacterial activity, in particular against Pseudomonas aeruginosa, while they were not effective in the inhibition of $C$. albicans growth $[17,36,37]$.

\subsubsection{Inhibition of $C$. albicans filamentous growth}

The yeast-to-hyphal transition represents the main virulence factor associated with the pathogenesis of $C$. albicans infections [59]. The hyphal formation is essential for $C$. albicans spp. to penetrate to human cells and invade tissues during the initial phases of infection, cause damages and form biofilms [27,60]. The effect of all investigated $\mathrm{Ag}(\mathrm{I})$ complexes on the $C$. albicans hyphal growth was evaluated on Spider medium [61]. In the sub-inhibitory concentrations (70\% of the MIC values), complexes $\mathbf{1 - 5}$, as well as 4,7-phen prevented the hyphal formation in comparison to DMSO control to different extent (Fig. 3). Only complex 3 completely inhibited the formation of hyphae in comparison to DMSO control. AgSD and nystatin also showed a potency to inhibit $C$. abicans filamentous growth on Spider medium. 

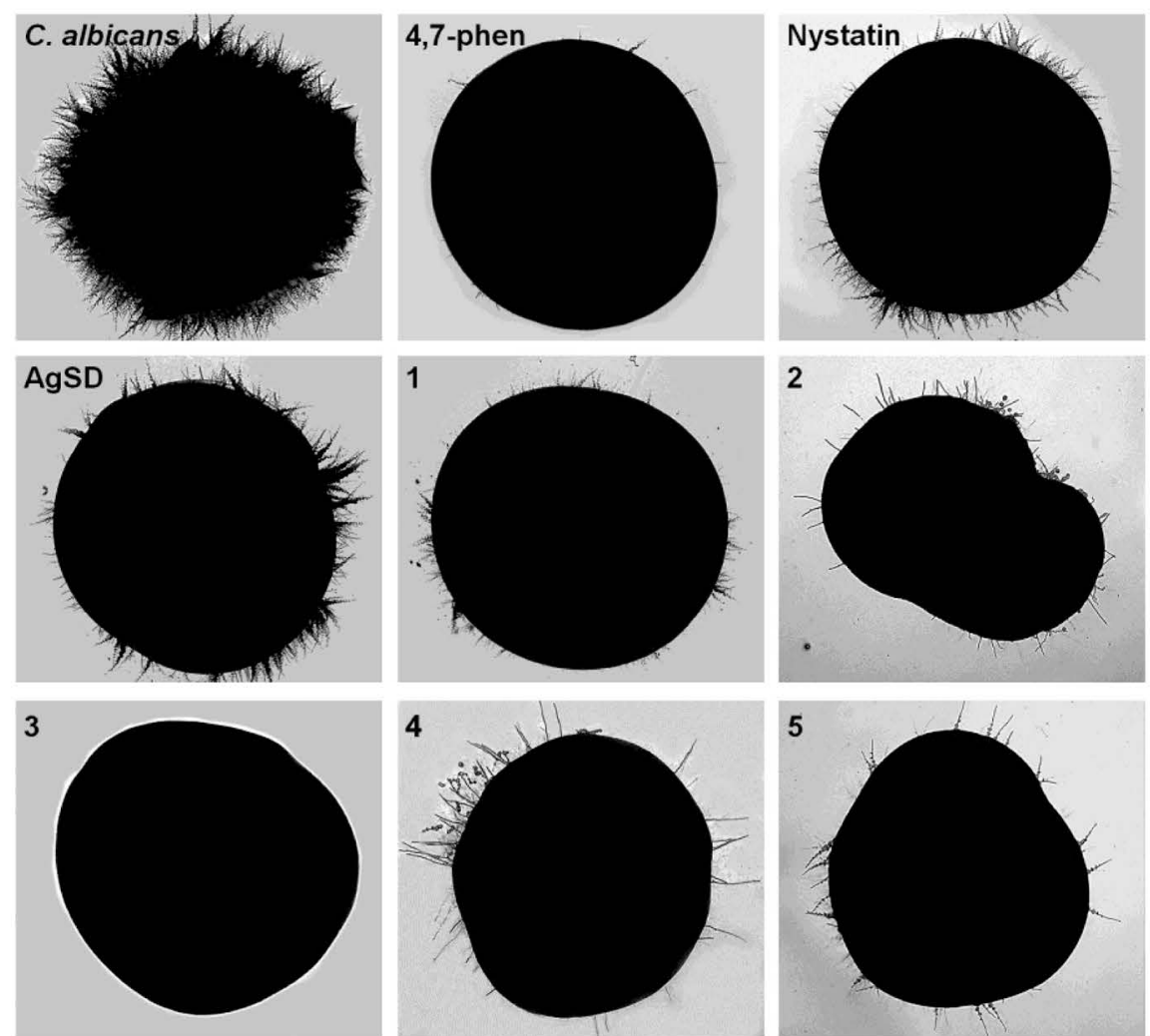

Fig. 3. The effect of sub-inhibitory concentration of the Ag(I) complexes 1-5 on C. albicans hyphal formation in comparison to AgSD, nystatin and 4,7-phenanthroline.

\subsubsection{Reactive oxygen species (ROS) generation in $G$. albicans}

A plausible mechanism of antifungal action of $\mathrm{Ag}(\mathrm{I})$ complexes can be attributed to the ROS generation [9]. The ROS are a by-product of normal cell metabolism however, overproduction of ROS may result in mitochondrial dysfunction and oxidative damage of DNA, eventually leading to the cell death [62]. Therefore, the $2^{\prime}, 7^{\prime}$-dichlorofluorescin diacetate (DCFH-DA) staining in the combination with flow cytometry was used for the quantification of ROS production in C. albicans cells treated with the MIC concentrations of $\mathrm{Ag}(\mathrm{I})$ complexes 1-5 (Fig. 4). The indication for ROS generation was $2^{\prime}, 7^{\prime}$-dichlorofluorescein (DCF)
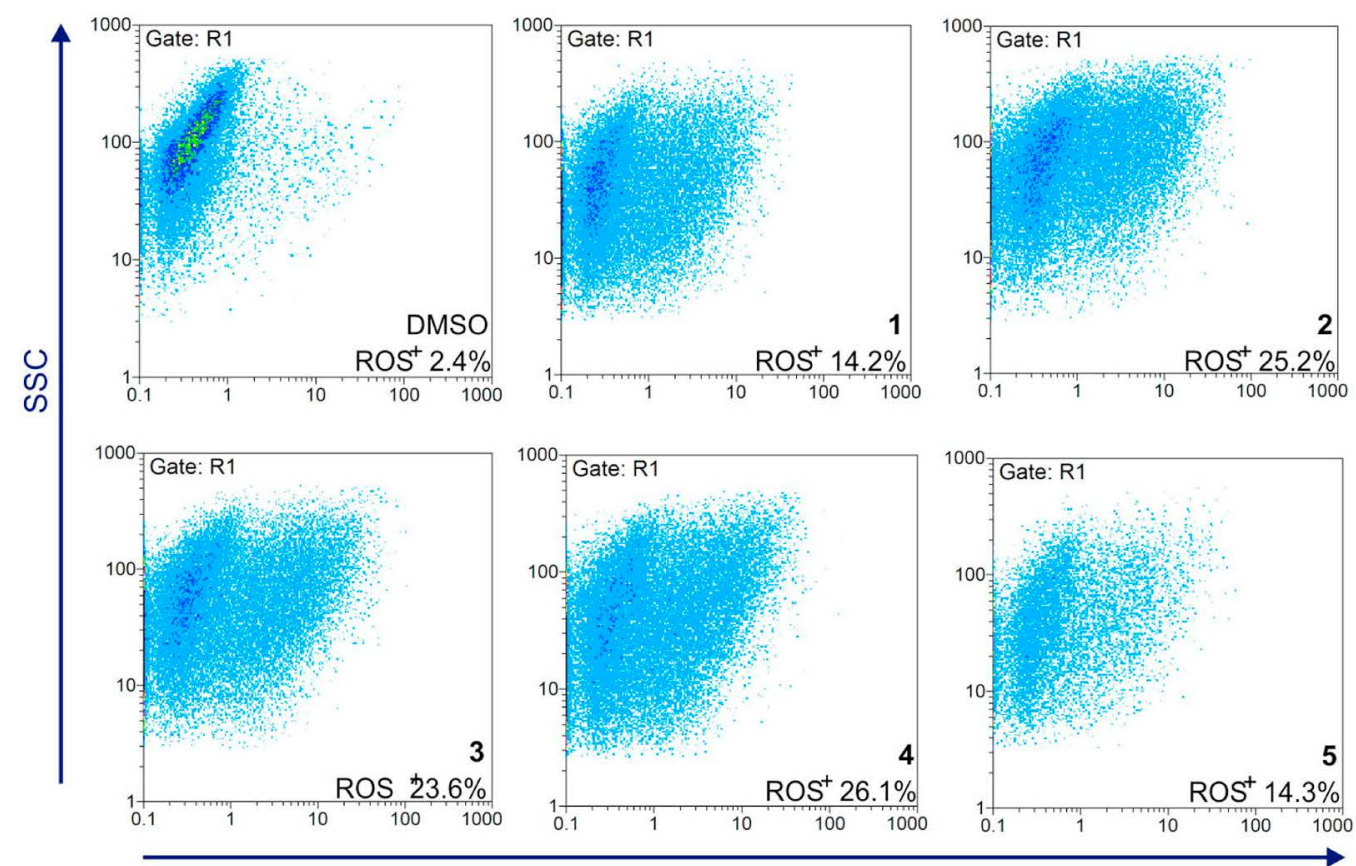

DCFH-DA

Fig. 4. Reactive oxygen species (ROS) generation in C. albicans cells treated with MIC concentrations of Ag(I) complexes 1-5. ROS were detected using 2',7'dichlorofluorescin diacetate (DCFH-DA) staining with cells treated with DMSO used as a control. 
fluorescence as a consequence of DCFH-DA oxidation (Fig. 4). The determination of cellular ROS generation by flow cytometry revealed notable increase in DCF fluorescence after $1 \mathrm{~h}$ of incubation with each of five $\mathrm{Ag}(\mathrm{I})$ complexes, whereas the effect was more pronounced upon treatment with the complexes 2,3 and $\mathbf{4}$ in comparison to that of $\mathbf{1}$ and 5 (Fig. 4). The obtained results suggested that the antifungal activity of $\mathrm{Ag}(\mathrm{I})$ complexes 1-5 could be due to the ROS generation, being in accordance with those previously published for mononuclear $\mathrm{Ag}(\mathrm{I})$ complexes with 1,7-phenanthroline [14]. Some other Ag(I) complexes were also reported to cause increased ROS levels in eukaryotic cells $[63,64]$.

\subsection{DNA interaction}

Recent reports highlighted a connection between antimicrobial activity of different $\mathrm{Ag}(\mathrm{I})$ complexes and DNA interactions, suggesting the potential mechanism of action of corresponding Ag(I) complexes [16]. A convenient technique for studying DNA interactions with different compounds is UV-Vis spectrophotometry. Considering this, in the present study, the changes in the absorption spectra of complexes 1-5 were investigated varying the concentration of polynucleotide (Fig. S5). For all studied complexes, hyperchromic effect was observed upon addition of ctDNA aliquots, suggesting the formation of a non-covalent interaction being addressed to either external contact with the phosphate backbone (electrostatic binding) or groove binding motif (major or minor) between the corresponding complex and this biopolymer [65]. From the obtained results it was found that complexes 1 and 5 bind stronger to the double stranded beta helix as opposed to the rest of the investigated complexes (Table S5). In general, the intrinsic binding constants $\left(K_{b}\right)$ for 1-5 are comparable with those determined for the [Ag(2,9-dimethyl-1,10-phen $\left.)_{2}\right] \mathrm{NO}_{3} \cdot \mathrm{H}_{2} \mathrm{O}$ complex [66]. However, the $K_{b}$ constants for 1-5 appear to be significantly lower compared to those previously determined for typical groove binders, among which are Hoechst $32258\left(K_{b}=4.6 \cdot 10^{5} \mathrm{M}^{-1}\right.$ with A3T3 duplex $)$ [67] and

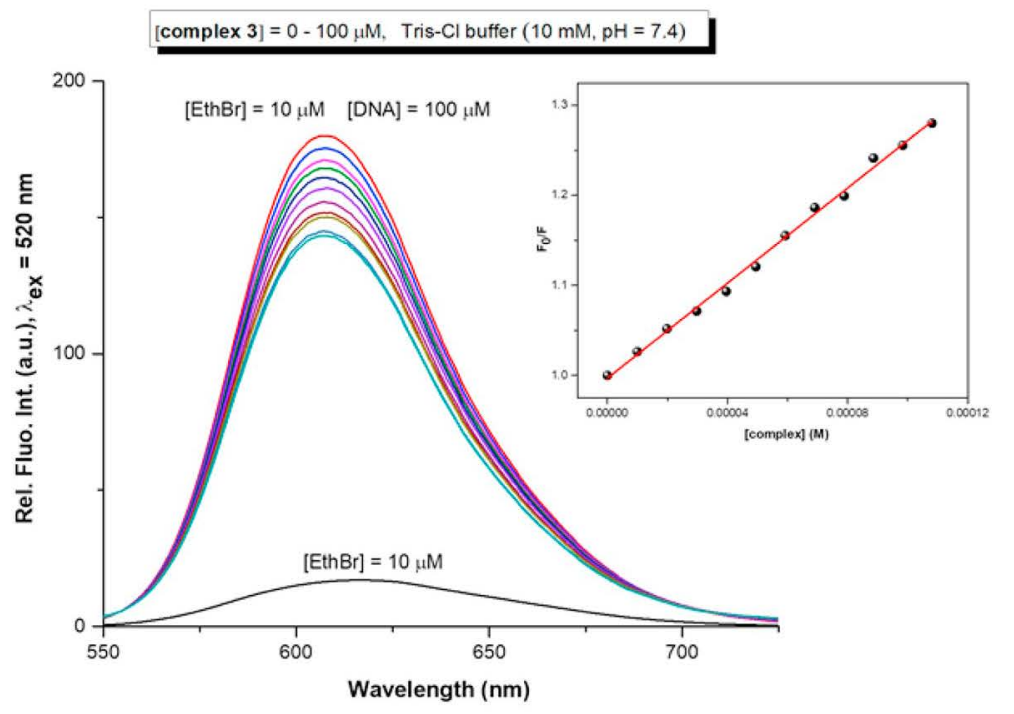

ethidium bromide (EthBr; $K_{b}=1.23 \cdot 10^{5} \mathrm{M}^{-1}$ ) [68]. The Gibbs energy $(\Delta \mathrm{G})$ calculated from the binding constant values $\left(\Delta \mathrm{G}=-\mathrm{RT} \ln K_{b}\right)$ was negative, pointing out the spontaneity of the interactions between the investigated complexes and ctDNA.

Fluorescence quenching experiments were performed using ctDNA treated with EthBr, aiming to determine the binding mode of the investigated complexes. The emission spectra for the interaction of the $\mathrm{Ag}$ (I) complexes 1-5 with EthBr-DNA at $298 \mathrm{~K}$ are represented in Figs. 5A and S6, while Fig. S7 depicts the plot of $\log \left(\mathrm{F}_{0}-\mathrm{F}\right) / \mathrm{F}$ versus $\log$ [complex], $\mathrm{F}_{0}$ and $\mathrm{F}$ stand for the fluorescence intensities in the absence and presence of the complexes, respectively. As can be seen, the addition of complexes to EthBr-DNA resulted in a notable attenuation of the emission intensity. A plausible explanation to the latter, might be addressed to the replacement of the intercalated $\mathrm{EthBr}$ from the EthBrDNA system by a complex, resulting in the decrease of EthBr concentration bound to DNA [69]. However, complexes can also bind to the EthBr-DNA, leading to the formation of a new non-fluorescence [complex]-EthBr-DNA system, which caused the fluorescence quenching of EthBr-DNA biocomplex. In our current study, the investigated complexes could not efficiently replace the EthBr. This observation can be deduced from the obtained binding constant values ( $K_{\mathrm{A}}$, Table S5), which appear to be considerably lower than that for EthBr itself $\left(K_{A}=2 \cdot 10^{6} \mathrm{M}^{-1}\right)$ [69]. Therefore, the second assumption seems to be more reasonable explanation for the decrease in fluorescence response of the EthBr-DNA system after the addition of the complex. The binding of complexes to DNA may affect the EthBr-DNA system, inducing the nonparallelism of EthBr molecular and DNA base planes, and consequently, fluorescence intensity decrease.

The potential of $\mathrm{Ag}(\mathrm{I})$ complexes to interact with linear doublestranded lambda bacteriophage DNA ( $48.5 \mathrm{~K}$ base pairs with a molecular weight of $31.5 \times 10^{6} \mathrm{Da}$ ) was also assessed via gel electrophoresis (Fig. 5B). In this experiment, lambda bacteriophage DNA was incubated with various concentrations of $\mathrm{Ag}(\mathrm{I})$ complexes and visualized by $\mathrm{EthBr}$
$A$

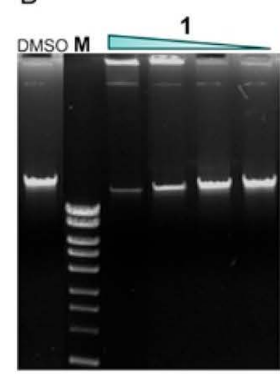

2

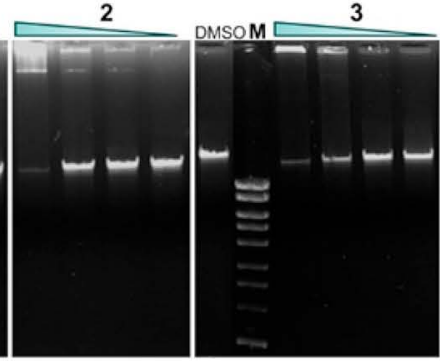

4

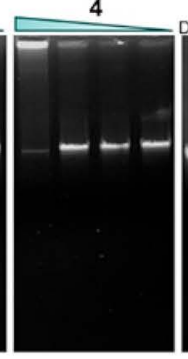

Fig. 5. (A) Fluorescence emission spectra of EthBr-DNA system in the presence of an increasing amount of complex 3; (B) In vitro interaction of $\mathrm{Ag}(\mathrm{I})$ complexes 1-5 with lambda bacteriophage DNA. (Treatment with decreasing amounts of $\mathrm{Ag}(\mathrm{I})$ complexes $(400,40,10$ and $5 \mu \mathrm{M}) ; \mathrm{DMSO}=$ treatment with DMSO; $\mathrm{M}=$ molecular marker peqGOLD 1 kb DNA-Ladder Plus). 
staining. Under the tested conditions, none of the $\mathrm{Ag}(\mathrm{I})$ complexes was able to interact with lambda bacteriophage DNA in a way to prevent EthBr binding and they were not causing DNA degradation (Fig. 5B). Upon treatment with higher concentrations of $\mathrm{Ag}(\mathrm{I})$ complexes 1-5, the phenomenon of gel retardation was observed when electrophoretic properties of lambda bacteriophage DNA were considerably affected, causing no movement of the complex-DNA. Overall, Ag(I) complexes did interact with lambda bacteriophage DNA, but this interaction has not caused DNA degradation, as it was shown for $[\mathrm{Ag}(1,10$-phendio $)_{2} \mathrm{ClO}_{4}$ complex (1,10-phendio is 1,10-phenanthroline-5,6-dione) that caused an extensive and non-specific DNA cleavage [11].

The Stern-Volmer constants $\left(K_{s v}\right)$ values for the complexes 1-5 appear to be significantly low, suggesting that they bind to DNA through the non-intercalative mode (Table S5). The $K_{s y}$ values follow the order $5>3-1>4>2$, which is in accordance with $K_{b}$ constants determined by UV-Vis spectroscopic data. Similar values of $K_{s v}$ constants were obtained for $\left[\mathrm{Ag}_{2}(\mathrm{HGly})_{2}\right]_{n}\left(\mathrm{NO}_{3}\right)_{2 n}$ and $\left[\mathrm{Ag}(\mathrm{Nam})_{2}\right] \mathrm{NO}_{3} \cdot \mathrm{H}_{2} \mathrm{O}$ complexes (Gly is glycine and Nam is nicotinamide) [70]. Moreover, the percentage of the hypochromism is low (up to $25 \%$ ), supporting the assumption of non-intercalative or a mixed binding motif. For instance, lucigenin which was proved as an intercalator caused a decrease of $50 \%$ in the emission intensity of EthBr-DNA [71]. The $K_{q}$ values for $\mathrm{Ag}(\mathrm{I})$ complexes 1-5 are higher than the limiting diffusion rate constant of the biomolecule $\left(2 \cdot 10^{10} \mathrm{M}^{-1} \mathrm{~s}^{-1}\right)$ indicating that the binding between them and DNA is a static quenching process [69].

The results observed for complexes - DNA interactions with cyclic voltammetry measurements are shown in Fig. S8, as representative voltammograms for complex 4. Under the tested experimental conditions, DNA shows two oxidation peaks: the first at potentials of around $1.0-1.1 \mathrm{~V}$ and the second at potential between 1.3 and $1.4 \mathrm{~V}$ which are connected to the oxidation of DNA bases, guanine and adenine, respectively [72]. The interaction between complexes and DNA shows that the addition of complexes in DNA solution is followed by the proportional decrease of peak current obtained for guanine and adenine (in comparison with control DNA) indicating that DNA become condensed after complexes - DNA interaction.

Taking all the latter into account, the binding mode between the complexes 1-5 and DNA is non-intercalative, but whether groove or the electrostatic binding is responsible for the DNA-complexes interaction remains unclear. Nevertheless, there is a connection between complexes' binding constants to DNA and percentage of ROS formation (Fig. 4), suggesting that the complexes having lower binding constants produced more ROS and vice versa, indicating their possible interaction with mitochondrial pathways.

\subsection{Toxicity and therapeutic safety of 1-5 in vivo}

In order to evaluate the therapeutic potential of $\mathrm{Ag}(\mathrm{I})$ complexes 1-5, they were examined for the toxicity in the zebrafish model. Zebrafish (Danio rerio) emerged as a versatile platform for drug discovery and toxicity assessment of pharmacologically active compounds, owing to their high genetic, molecular and immunological similarities to mammals, including humans, and very good correlation in response to pharmaceuticals, simplifying thus the path to clinical trials and reducing the failure of potential therapeutics at later stages of testing [73-75]. In this study, zebrafish embryos were exposed to different doses of 1-5 during a period from 38 to $120 \mathrm{hpf}$ and analyzed for survival and different adverse side effects. According to the determined $\mathrm{LC}_{50}$ (the concentration inducing the lethal effect of $50 \%$ embryos) values (Fig. 6), the tested complexes were ranked by the decreasing toxicity as follows: $\mathbf{4}>\mathbf{5}>\mathbf{2}>3>1$. We observed that all tested compounds exerted the same side effects, weak cardiotoxicity manifested as an appearance of weak pericardial edema and weak hepatotoxicity at higher doses (Fig. S9).

Determination of the toxicity of $\mathrm{Ag}(\mathrm{I})$ complexes allowed the calculation of their therapeutic index (Ti; a ratio between $\mathrm{LC}_{50}$ and MIC dose) and the therapeutic window ( $\mathrm{Tw}$; a ratio between $\mathrm{EC}_{50}$ and MIC dose; $\mathrm{EC}_{50}$ is the concentration inducing side effects (lethality and teratogenicity) at $50 \%$ embryos) (Table 2). Out of the investigated complexes, 1, 3 and 5 showed the best therapeutic profiles, without toxic effects at $2 \times$ MIC values. The best Tw value was determined for complex 1. Therefore, these three complexes have been selected for the evaluation of their antifungal efficacy in vivo in the C. albicans-zebrafish infection model.

\subsubsection{Antifungal efficacy of 1,3 and 5 in vivo in the $C$. albicans-zebrafish infection model}

The zebrafish (Danio rerio) has been recognized as an important alternative to mammalian models for studying the host-pathogen interactions. The model of disseminated candidiasis in larval zebrafish

Table 2

Evaluation of the therapeutic index (Ti) and the therapeutic window (Tw) of silver(I) complexes 1-5.

\begin{tabular}{lccccc}
\hline Complex & MIC $(\mu \mathrm{M})$ & $\mathrm{LC}_{50}(\mu \mathrm{M})$ & $\mathrm{EC}_{50}(\mu \mathrm{M})$ & $\mathrm{Ti}\left(\mathrm{LC}_{50} / \mathrm{MIC}\right)$ & $\mathrm{Tw}\left(\mathrm{EC}_{50} / \mathrm{MIC}\right)$ \\
\hline 1 & 6.2 & 31.94 & 27.77 & 5.15 & 4.48 \\
2 & 6.2 & 9.91 & 9.04 & 1.60 & 1.46 \\
3 & 3.1 & 12.18 & 10.60 & 3.93 & 3.42 \\
4 & 3.1 & 5.76 & 5.53 & 1.86 & 1.78 \\
5 & 3.1 & 7.93 & 7.63 & 2.56 & 2.46 \\
\hline
\end{tabular}

MIC - the minimal inhibitory concentration determined against $C$. albicans CS5314.

$\mathrm{LC}_{50}$ - the concentration causing lethal effect at $50 \%$ zebrafish embryos.

$\mathrm{EC}_{50}$ - the concentration inducing side effects (lethality and teratogenicity) at $50 \%$ embryos.

$\mathrm{Ti}$ - the therapeutic index determined as the ratio between $\mathrm{LC}_{50}$ value and $\mathrm{MIC}$ value.

$\mathrm{Tw}$ - the therapeutic window (therapeutic safety index) determined as the ratio between $\mathrm{EC}_{50}$ value and MIC value.

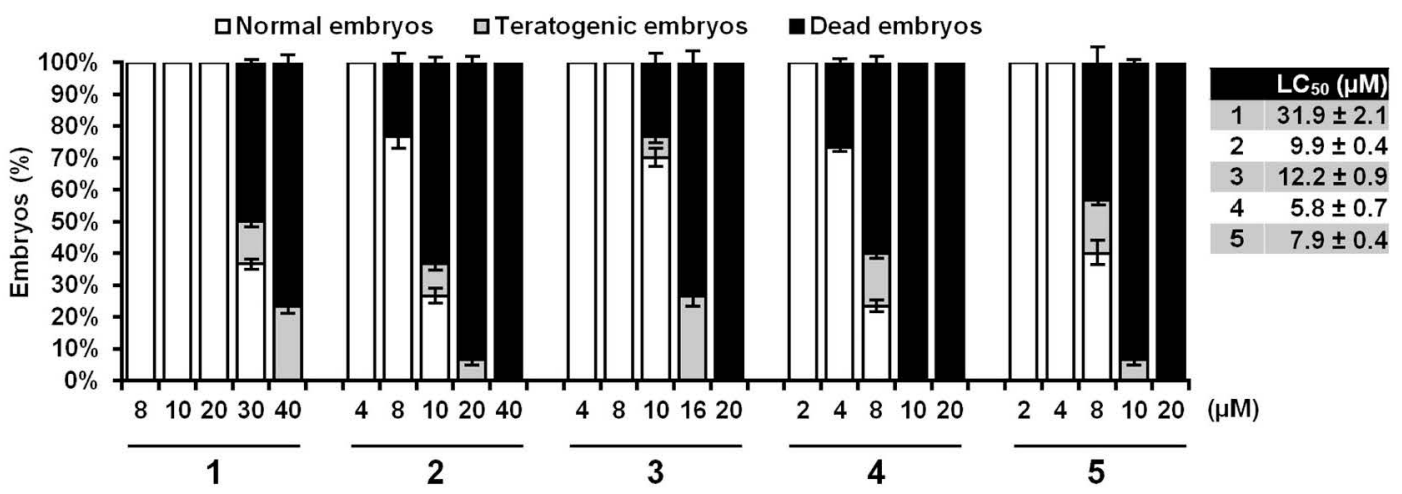

Fig. 6. The toxicity of $\mathrm{Ag}(\mathrm{I})$ complexes 1-5 in the zebrafish embryos treated in the period from 38 to $120 \mathrm{hpf}$. 
has particularly proven useful to address an effectiveness of anticandidal therapy, enabling to dissect host and pathogen interactions and to track the yeast-to-hyphae transition, pathogen dissemination and early host immune response upon applied therapy [29,30]. With the aim to evaluate the antifungal efficacy of complexes 1,3 and 5 in vivo thoroughly, we employed the $C$. albicans-zebrafish infection model. The therapeutic efficacy of the selected complexes was assessed by the survival of the infected embryos and the fungal burden within them (Fig. 7).

In this study, the microinjection of 40-65 the GFP-labeled cells of $C$. albicans CS5314 into the hindbrain through the otic vesicle resulted in the mortality of $\sim 70 \%$ of zebrafish embryos by 4 days post infection (dpi), where more than a half of the infected embryos $(53 \%)$ died within first 2 dpi (Fig. 7). In turn, the survival of the infected embryos upon each of the tested $\mathrm{Ag}(\mathrm{I})$ complexes was markedly increased by 4 dpi ( $p<0.001$, Log rank test) (Fig. 7A-C). Already at the first $24 \mathrm{~h}$ post treatment (hpt), the survival of the treated infected embryos was significantly higher even at $1 / 2 \times$ MIC dose of each complex than in the untreated group (85-90\% versus 70\%; p $<0.001$, Log rank test), indicating that the antifungal complexes were effective early in the infection treatment. According to the Kaplan-Meier survival curves, 1 was the most effective complex against the lethal disseminated candidiasis, where almost all fish $(97.5 \%)$ survived the infection at $1 \times$ MIC and $2 \times$ MIC doses by $4 \mathrm{dpi}$, while the survival rate at $1 / 2 \times$ MIC dose was lower, but still 2.2-fold higher than in the untreated group (72.5 vs. 32.5\%) (Fig. 7A). Similar effects have been observed in therapy with 3 at $1 \times$ MIC and $2 \times$ MIC doses, but lower number of rescued embryos was achieved at $1 / 2 \times$ MIC dose of 3 than that of $1(60$ vs. $72.5 \%)$ (Fig. 7B).

In turn, complex 5 which had higher in vitro antifungal activity against the tested $C$. albicans strains than 1 and 3 (Table 2) demonstrated lower efficiency in vivo, and surprisingly, was active in an inverse dose-dependent manner. During the first $24 \mathrm{hpt}$, complex 5, similarly to 1 and 3 , rescued embryos from candidal infection in a dosedependent manner (Fig. 7C). However, at 2 dpi onwards, the survival of the infected embryos declined with an increase of concentration of $\mathbf{5}$, and at $4 \mathrm{dpi}$, the highest survival rate was found in the group upon $1 / 2 \times$ MIC dose and the lowest survival at $2 \times$ MIC dose (Fig. 7C). Such an unpredictable outcome of the antifungal therapy with $\mathbf{5}$ was not due

A)

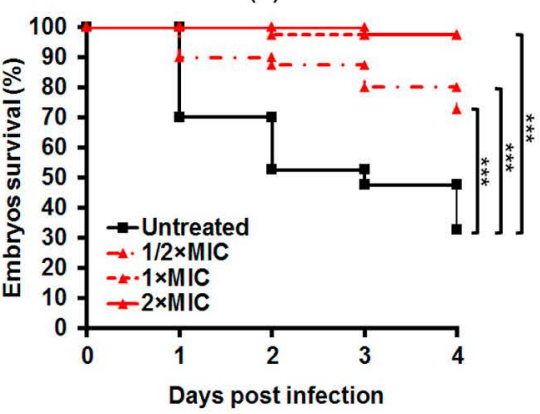

C)

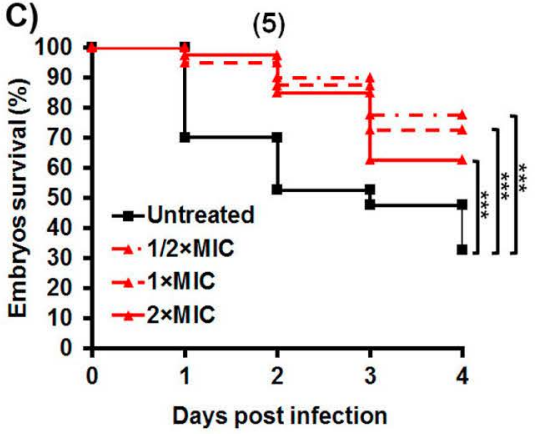

\section{(1)}

Days post infection
B)
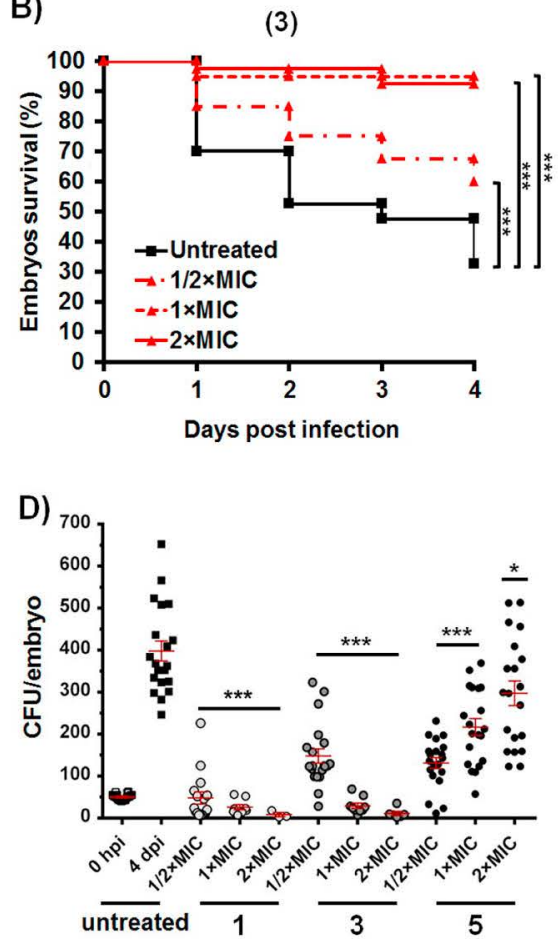

to the complex toxicity, since the all uninfected embryos exposed to the tested doses of 5 at $38 \mathrm{hpf}$ onwards were alive and without visible signs of teratogenicity at $120 \mathrm{hpf}$ (data not shown).

In order to address the effect of the applied antifungal complexes on the burden of $C$. albicans CS5314, the infected embryos were crashed on $4 \mathrm{dpi}$ and counted for colony forming units (CFUs). The obtained results revealed that complexes 1 and 3 , at each of the applied doses, significantly reduced the number of fungal cells by $4 \mathrm{dpi}$, compared to that of the untreated group ( $p<0.0001$, ANOVA, Bonferroni test) (Fig. 7D). While the fungal cells were present in each analyzed live embryo from the untreated group at $4 \mathrm{dpi}$ and reached up to $6.5 \times 10^{2}$ CFUs per embryo (Fig. 7D), the fungal loads in the treated embryos were significantly lower ( $p<0.0001$, ANOVA, Bonferroni test), particularly upon treatment with complex 1 . After the 3 days treatment with 1, 20,60 and $85 \%$ of the analyzed embryos were free of fungal infection at $1 / 2 \times$ MIC, $1 \times$ MIC and $2 \times$ MIC doses, respectively, since no CFU has been recorded after their plating on YPD media; the fungal load in the remaining treated embryos where infection was detected by plating was significantly lower than in the untreated group ( $\mathrm{p}<0.0001$ ) and up to $2.3 \times 10^{2}, 5.6 \times 10^{1}$ and $1.8 \times 10^{1}$, respectively. In comparison to the untreated group (an average CFU of $398 \pm 106$ ), the fungal burden upon the therapy with 1 was reduced from 10 -fold at $1 / 2 \times$ MIC dose to 331 -fold at $2 \times$ MIC dose. Similarly, the embryos infection with $C$. albicans was noticeably eradicated by complex 3 , but less efficiently than by 1 , since fungal burden and embryos mortality were higher in the treatment with 3 then with 1 . On the other side, complex 5 exhibited a poor potential to cure candidal infection in vivo, since the fungal cells were present in all analyzed zebrafish embryos at $4 \mathrm{dpi}$, attaining $2.3 \times 10^{2}(1 / 2 \times \mathrm{MIC}), 4.2 \times 10^{2}$ $\left(1 \times\right.$ MIC) and $5.1 \times 10^{2}(2 \times$ MIC). Nevertheless, the fungal burden upon the therapy with 5 followed the observed pattern of embryos survival (Fig. 7D).

The yeast-to-hyphae transition represents the main virulence factor associated with the pathogenesis of $C$. albicans infection, enabling the fungal cells to invade tissues, cause damages and form biofilms [76]. In the previous studies, Brothers et al [29] and Mallick et al [30] demonstrated that the filamentation is very important for the $C$. albicans virulence in zebrafish as a host, since the mutant strains deficient in the filamentation showed markedly reduced host killing. In this study, we

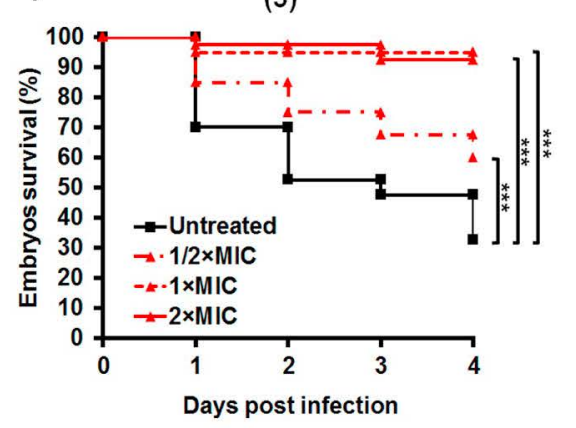
Log rank (Mantel-Cox) test $\left({ }^{*} p<0.05,{ }^{* *} p<0.01\right.$, dpi by plating of the crushed embryos for colony forming units (CFUs). Data are compilation of two independent experiments using ten embryos for each group. Each dot represents an individual fish (square - untreated embryos, circle - treated embryos). The mean CFUs \pm SEM are shown. Statistically significant differences between the treated and untreated groups were determined using a Student's $t$-test $\left({ }^{*} p<0.05,{ }^{* * *} p<0.01,{ }^{* * * *} p<0.001\right)$. 


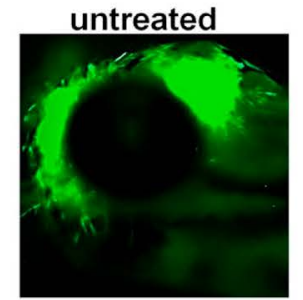

$1 / 2 \times$ MIC
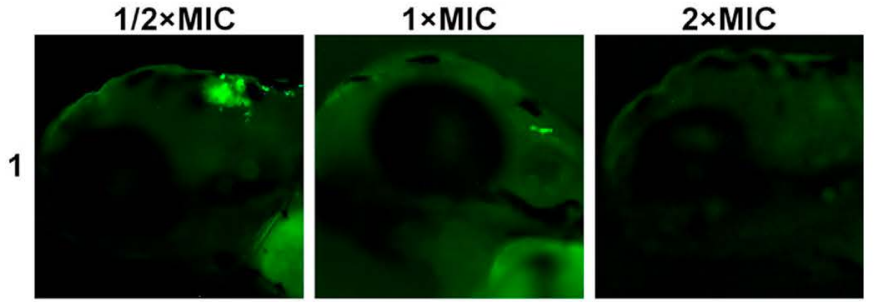

3
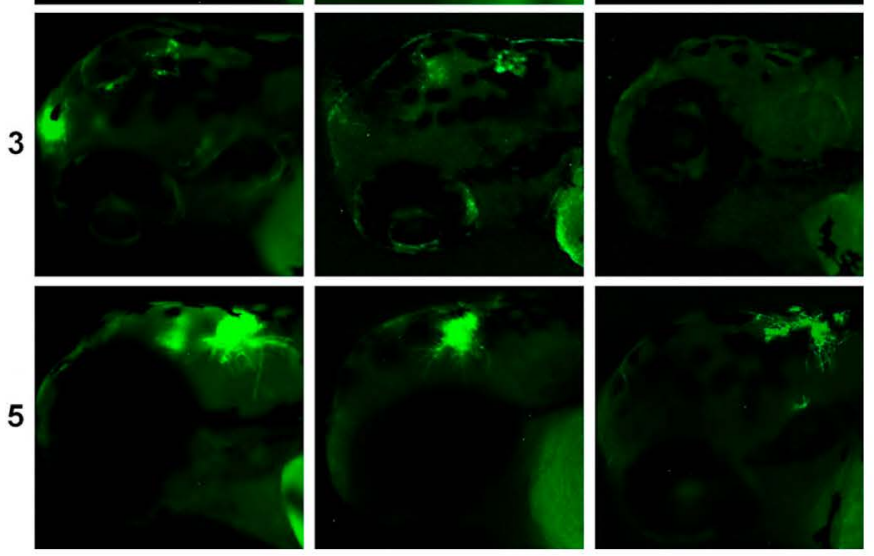

Fig. 8. The filamentation of GFP-labeled $C$. albicans cells in the wild type zebrafish embryos at $48 \mathrm{~h}$ after treatment with different doses $(1 / 2 \times \mathrm{MIC}$, $1 \times \mathrm{MIC}$ and $2 \times \mathrm{MIC}$ ) of the $\mathrm{Ag}(\mathrm{I})$ complexes 1,3 and 5 . The fungal cells fillamented within the hindbrain of the infected untreated embryos a few hours after injection, spreaded over the entire head and penetrated the head epithelium by $1-2$ dpi (untreated).

analyzed the effect of complexes 1,3 and 5 on the fungal filamentation in vivo, after microinjection of the fungal cells into the hindbrain of zebrafish embryos and we observed that the survival rate of the infected untreated embryos was in strong correlation with the level of fungus filamentation (dissemination). In majority of the untreated embryos, $C$. albicans cells filamented within the hindbrain a few hours after injection and disseminated through the whole body, whereas both yeast and filamentous fungi have been observed at 2 dpi. In all moribund embryos at $2 \mathrm{dpi}, C$. albicans cells have formed a dense network of filaments within the head and penetrated the head epithelium in some of them. However, no filamentous structures were observed within body of the untreated fish that survived $C$. albicans infection by $4 \mathrm{dpi}$, whereas the fungal cells were mainly detected within the head and intestine (Fig. S10), what is in a line with the findings of Brothers et al. [76].

On the other side, we found that complexes 1 and 3 efficiently inhibited C. albicans cells filamentation in vivo in a dose-dependent manner (Fig. 8). By $2 \mathrm{dpi}$, when $52 \%$ of the untreated embryos died upon infection, the filamentation was completely inhibited by the treatment with the doses $\geq 1 / 2 \times$ MIC of 1 and $\geq 1 \times$ MIC of 3 (Fig. 8); at $1 / 2 \times$ MIC of 3 , the fungal hyphae have rarely been found within the body of infected embryos and were very short, thin and non-branched, like those formed in the Spider medium at $0.7 \times$ MIC of 3 (Fig. 3). These data indicated that the investigated complexes have successfully rescued the infected embryos in part due to successful prevention of fungal filamentation. Contrary to 1 and 3 , complex $\mathbf{5}$ failed to inhibit the $C$. albicans cells filamentation at any of applied doses by $2 \mathrm{dpi}$ (Fig. 8). However, by $4 \mathrm{dpi}$, the infection has increased with the increasing concentrations of 5 , whereas the most abundant filamentation and fungal mass occurred at $2 \times$ MIC dose, and vice versa (Fig. S10), while filamentous structures have not been found in the untreated fish. The later findings lead us to investigate the potential immunotoxicity of complex $\mathbf{5}$, due to the fact that the neutrophils are critical immune cells for antifungal defense, since they are the only host cells capable of successfully inhibiting the germination of Candida yeasts into hyphae and preventing dissemination of $C$. albicans infection $[77,78]$.

Brothers et al. found that efficient early phagocytosis blocks the yeast-to-hyphal switch and plays an important role in limiting invasion and mortality in vivo in the zebrafish model [76]. In addition, the conserved immunity was found pivotal in preventing lethal $C$. albicans invasive growth in the zebrafish, where neutrophils present major immune players which inhibit fungal filamentation and lethal dissemination $[30,76,79]$. In order to address immunotoxicity of the tested complexes, in this study we used transgenic $T g$ (mpx:EGFP) zebrafish line with a fluorescently labeled neutrophils, enabling thus a direct visualization of the neutrophils occurrence upon the treatment with the selected silver(I) complexes. The healthy, non-infected embryos were exposed to the complexes at the same time when antifungal treatments were applied ( $38 \mathrm{hpf}$ onwards). The obtained data revealed that 1 and 3 were not myelotoxic, since they did not affect the neutrophils occurrence at any of applied doses (Fig. 9A).

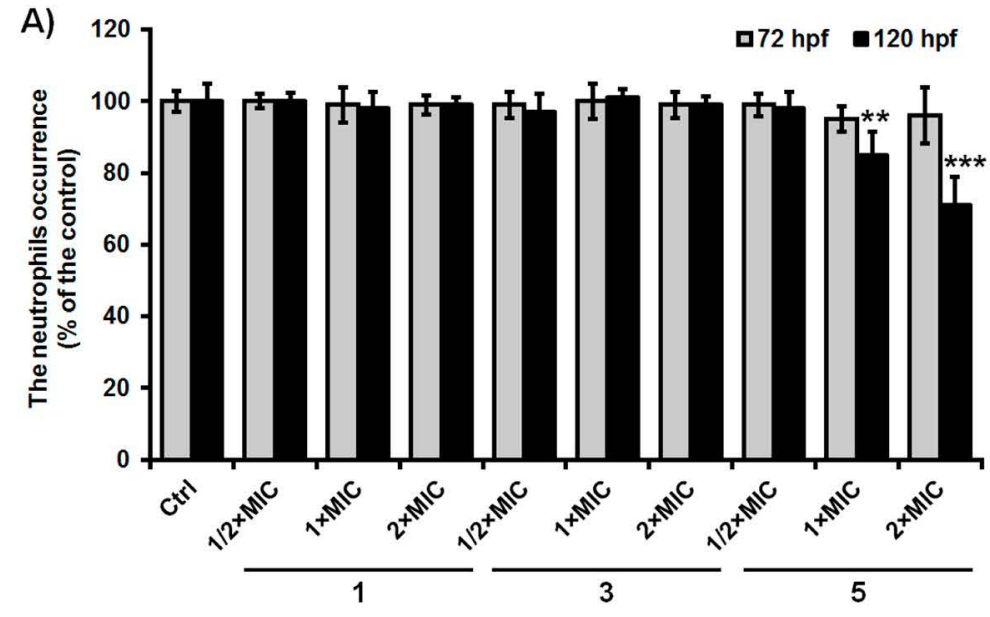

B)

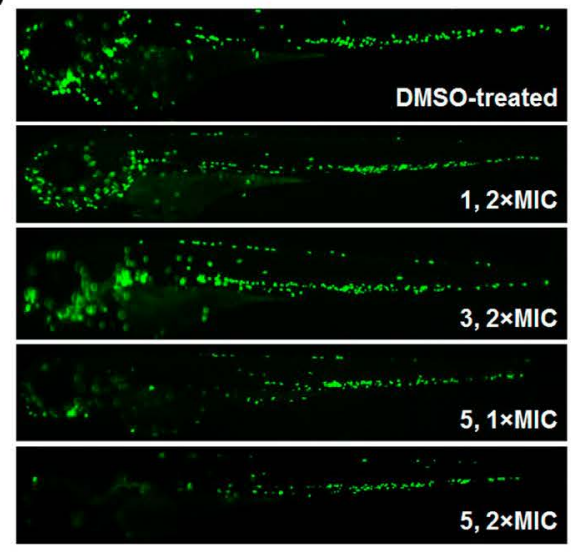

Fig. 9. The neutrophils occurrence (A) and fluorescence (B) in the transgenic Tg(mpx:EGFP) zebrafish larvae at 120 hpf ( 4 dpi) exposed to the different concentration of the investigated complexes in a period $38-120$ hpf. Statistically significant differences between the treated and untreated groups were determined using ANOVA and Bonferroni test $\left({ }^{*} \mathrm{p}<0.05, * * \mathrm{p}<0.01,{ }^{* * *} \mathrm{p}<0.001\right)$. 
On the other hand, complex 5 significantly reduced the number of neutrophils by $120 \mathrm{hpf}$ in the fish treated with $1 \times$ MIC and $2 \times$ MIC doses, but not with $1 / 2 \times$ MIC (Fig. 9B), while this effect has not been so pronounced earlier, at the $72 \mathrm{hpf}$ stage. This result may reflect the final therapeutic outcome that we observed in the infection model experiment, when $1 \times$ MIC and $2 \times$ MIC of 5 had the lower antifungal efficiency in comparison to $1 / 2 \times$ MIC (Fig. 7C), and indicates that the final outcome of the therapy with 5 on $C$. albicans infection can be a result of the interplay between its antifungal and myelosuppressive activities.

\section{Conclusion}

In the present study, five novel silver(I) complexes with 4,7-phenanthroline (4,7-phen) as ligand (1-5) have been synthesized, structurally characterized and evaluated for in vitro and in vivo biological activities. The reactions between $\mathrm{AgX}\left(\mathrm{X}=\mathrm{NO}_{3}{ }^{-}, \mathrm{CF}_{3} \mathrm{COO}^{-}\right.$and $\left.\mathrm{BF}_{4}{ }^{-}\right)$ and 4,7-phen in a 2: 1 molar ratio led to the formation of the polynuclear $\left[\mathrm{Ag}\left(\mathrm{NO}_{3}-\mathrm{O}\right)(4,7-\text { phen- } \mu-N 4, N 7)\right]_{\mathrm{n}}(1), \quad\left[\mathrm{Ag}\left(\mathrm{CF}_{3} \mathrm{COO}-\mathrm{O}\right)(4,7-\right.$ phen- $\mu-N 4, N 7)]_{\mathrm{n}}(3)$ and $\left\{\left[\mathrm{Ag}_{2}\left(\mathrm{H}_{2} \mathrm{O}\right)(4,7-\text { phen }-\mu-N 4, N 7)_{2}\right]\left(\mathrm{BF}_{4}\right)_{2}\right\}_{\mathrm{n}}(5)$ complexes, while of 4,7-phen with equimolar amounts of $\mathrm{AgClO}_{4}$ and $\mathrm{AgSbF}_{6}$ yielded the polynuclear $\left[\mathrm{Ag}\left(\mathrm{ClO}_{4}-\mathrm{O}\right)(4,7 \text {-phen- } \mu-\mathrm{N} 4, \mathrm{N7})\right]_{\mathrm{n}}(2)$ and dinuclear $\left[\mathrm{Ag}_{2}\left(\mathrm{H}_{2} \mathrm{O}\right)_{0.58}(4,7-\mathrm{phen})_{3}\right]\left(\mathrm{SbF}_{6}\right)_{2}$ (4) complexes. The mode of coordination of this $N$-heterocyclic ligand towards the $\mathrm{Ag}(\mathrm{I})$ ion was found to be governed by both steric and electronic factors. Based on molar conductivity measurements it was found that a release of coordinated $\mathrm{NO}_{3}{ }^{-}, \mathrm{ClO}_{4}{ }^{-}$and $\mathrm{CF}_{3} \mathrm{COO}^{-}$in complexes 1-3, respectively, occurred after their dissolution in DMSO and DMF solvents. Complexes 1-5 demonstrated strong selective activity towards the in vestigated Candida species in comparison to the bacterial strains, especially against $C$. albicans, and lower cytotoxicity towards healthy human fibroblasts than the clinically used silver(I) sulfadiazine. Among them, complexes 1 and 3 exhibited no developmental toxicity, cardiotoxicity nor immunotoxicity at the therapeutic (MIC) or higher doses. More importantly, at the sub-therapeutic doses, both complexes efficiently inhibited $C$. albicans filamentation, reduced fungal burden and rescued all infected zebrafish embryos of lethal disseminated candidiasis in vivo. Further assessment indicated the multifaceted mode of action of the described complexes, which includes interaction with DNA and generation of reactive oxygen species leading to eventual $C$. albicans cells death. Taken together, the results obtained in this study clearly indicate that the $\mathrm{Ag}(\mathrm{I})$ complexes $\mathbf{1}$ and $\mathbf{3}$ present novel effective metal-based antifungal compounds with possible application in antifungal therapy against lethal $C$. albicans infection.

\section{Ethical statement}

All experiments involving zebrafish were performed in compliance with the European directive 2010/63/EU and the ethical guidelines of the Guide for Care and Use of Laboratory Animals of the Institute of Molecular Genetics and Genetic Engineering, University of Belgrade.

Notes

The authors have no competing interests to declare.

\section{Acknowledgements}

This research has been financially supported by the Ministry of Education, Science and Technological Development of the Republic of Serbia, under Grants nos. 172036 and 173048, the SupraMedChem@ Balkans. Net SCOPES Institutional Partnership (Project no. IZ74Z0_160515) and the Serbian Academy of Sciences and Arts (Project No. F128). DMS was supported by Magbiovin project (FP7-ERAChairsPilot Call-2013, Grant agreement: 621375). Professor Bernard Hube and Ms. Marina Pekmezovic (Department of Microbial Pathogenicity Mechanisms, Hans Knöll Institute, Jena, Germany) are acknowledged for providing GFP expressing strain M137 of C. albicans CS5314. Dr. Ana Cvejic (Wellcome Trust Sanger Institute, Cambridge, UK) is acknowledged for providing transgenic zebrafish embryos.

\section{Appendix A. Supplementary data}

Supplementary Material associated with this article includes NMR spectra $\left({ }^{1} \mathrm{H}\right.$ and $\left.{ }^{13} \mathrm{C}\right)$ for $1-5$, Figs. $\mathrm{S} 1-\mathrm{S} 10$ and Tables S1-S5. Crystallographic data for have been deposited with the Cambridge Crystallographic Data Centre (CCDC-1879001 (1), 1879002 (2), 1879003 (3), 1879004 (4) and 1880758 (5)). Copies may be obtained free of charge on application to the Director, CCDC, 12 Union Road, Cambridge CB2 1EZ, UK (e-mail: deposit@chemcrys.cam.ac.uk). Supplementary data associated with this article can be found in the online version, at https://doi.org/10.1016/j.jinorgbio.2019.03.017.

\section{References}

[1] E. Paramythiotou, F. Frantzeskaki, A. Flevari, A. Armaganidis, G. Dimopoulos, Molecules 19 (2014) 1085-1119.

[2] M.A. Pfaller, S.A. Messer, G.J. Moet, R.N. Jones, M. Canstanheira, Int. J. Antimicrob. Agents 38 (2011) 65-69.

[3] J.C.O. Sardi, L. Scorzoni, T. Bernardi, A.M. Fusco-Almeida, M.J.S. Mendes Giannini, J. Med. Microbiol. 62 (2013) 10-24.

[4] T. Roemer, D.J. Krysan, CSH Perspect. Med. 4 (2014) 1-14.

[5] S. Wu, Y. Wang, N. Liu, G. Dong, C. Sheng, J. Med. Chem. 60 (2017) 2193-2211.

[6] G. Gasser, N. Metzler-Nolte, Curr. Opin. Chem. Biol. 16 (2012) 84-91.

[7] I. Ali, W.A. Wani, A. Khan, A. Haque, A. Ahmad, K. Saleem, N. Manzoor, Microb. Pathog. 53 (2012) 66-73.

[8] L. Scorzoni, A.C.A. de Paula e Silva, C.M. Marcos, P.A. Assato, W.C.M.A. de Melo, H.C. de Oliveira, C.B. Costa-Orlandi, M.J.S. Mendes-Giannini, A.M. Fusco-Almeida, Front. Microbiol. 8 (2017) 36.

[9] S. Eckhardt, P.S. Brunetto, J. Gagnon, M. Priebe, B. Giese, K.M. Fromm, Chem. Rev. 113 (2013) 4708-4754.

[10] B. Coyle, K. Kavanagh, M. McCann, M. Devereux, M. Geraghty, Biometals 16 (2003) 321-329.

[11] M. McCann, B. Coyle, S. McKay, P. McCormack, K. Kavanagh, M. Devereux, V. McKee, P. Kinsella, R. O'Connor, M. Clynes, Biometals 17 (2004) 635-645.

[12] A. Eshwika, B. Coyle, M. Devereux, M. McCann, K. Kavanagh, Biometals 17 (2004) 415-422.

[13] R. Rowan, C. Moran, M. McCann, K. Kavanagh, Biometals 22 (2009) 461-467.

[14] N.D. Savić, S. Vojnovic, B.D. Glišić, A. Grochet, A. Pavic, G.V. Janjić, M. Pekmezović, I.M. Opsenica, K.M. Fromm, J. Nikodinovic-Punic, M.I. Djuran, Eur. J. Med. Chem. 156 (2018) 760-773.

[15] S. Aslam, A.A. Isab, M.A. Alotaibi, M. Saleem, M. Monim-ul-Mehboob, S. Ahmad, I. Georgieva, N. Trendafilova, Polyhedron 115 (2016) 212-218.

[16] M. Mujahid, N. Trendafilova, A.F. Arfa-Kia, G. Rosair, K. Kavanagh, M. Devereux, M. Walsh, S. Mcclean, B.S. Creaven, I. Georgieva, J. Inorg. Biochem. 163 (2016) $53-67$.

[17] N.D. Savić, B.D. Glišić, H. Wadepohl, A. Pavic, L. Senerovic, J. Nikodinovic-Runic, M.I. Djuran, MedChemComm 7 (2016) 282-291.

[18] G.K. Patra, I. Goldberg, S. De, D. Datta, CrystEngComm 9 (2007) 828-832.

[19] O.V. Dolomanov, L.J. Bourhis, R.J. Gildea, J.A.K. Howard, H. Puschmann, J. Appl. Crystallogr. 42 (2009) 339-341.

[20] G.M. Sheldrick, Acta Crystallogr. A 71 (2015) 3-8.

[21] G.M. Sheldrick, Acta Crystallogr. C 71 (2015) 3-8.

[22] I.J. Bruno, J.C. Cole, P.R. Edgington, M. Kessler, C.F. Macrae, P. McCabe J. Pearson, R. Taylor, Acta Crystallogr. B 58 (2002) 389-397.

[23] A. Wolfe, G.H. Shimer Jr., T. Meehan, Biochemistry 26 (1987) 6392-6396.

[24] P. Smolénski, C. Pettinari, F. Marchetti, M.F.C. Guedes da Silva, G. Lupidi, G.V.B. Patzmay, D. Petrelli, L.A. Vitali, A.J.L. Pomberio, Inorg. Chem. 54 (2015) 434-440.

[25] M.B. Hansen, S.E. Nielsen, K. Berg, J. Immunol. Methods 119 (1989) 203-210.

[26] V. Ajdačić, L. Senerovic, M. Vranić, M. Pekmezovic, V. Arsic-Arsnijevic, A. Veselinovic, J. Veselinovic, B.A. Šolaja, J. Nikodinovic-Runic, I.M. Opsenica, Bioorg. Med. Chem. 24 (2016) 1277-1291.

[27] L. Sun, K. Liao, C. Hang, D. Wang, PLoS One 12 (2017) e0172228.

[28] OECD, OECD Guidelines for the Testing of Chemicals, Test No. 236, (2013).

[29] K.M. Brothers, RT. Wheeler, J. Vis. Exp. 65 (2012) e4051.

[30] E.M. Mallick, A.C. Bergeron, S.K. Jones Jr., Z.R. Newman, K.M. Brothers, R. Creton, RT. Wheeler, R.J. Bennett, Front. Microbiol. 7 (2016) 780.

[31] C.W. Kim, J. Ahn, S.M. Kim, T.H. Noh, O.-S. Jung, Transit. Met. Chem. 36 (2011) $545-551$.

[32] W.J. Geary, Coord. Chem. Rev. 7 (1971) 81-122.

[33] P.E. Aranha, M.P. dos Santos, S. Romera, E.R. Dockal, Polyhedron 26 (2007) 1373-1382.

[34] L. Yang, D.R. Powell, R.P. Houser, Dalton Trans. (2007) 955-964.

[35] C. Pettinari, F. Marchetti, G. Lupidi, L. Quassinti, M. Brarnucci, D. Petrelli, L.A. Vitali, M.F.C.G. da Silva, L.M.D.R.S. Martins, P. Smoleński, A.J. Pombeiro, Inorg. Chem. 50 (2011) 11173-11183. 
[36] N.D. Savić, D.R. Milivojevic, B.Đ. Glišić, T. Ilic-Tomic, J. Veselinovic, A. Pavic, B. Vasiljevic, J. Nikodinovic-Runic, M.I. Djuran, RSC Adv. 6 (2016) 13193-13206.

[37] B.D. Glišić, L. Senerovic, P. Comba, H. Wadepohl, A. Veselinovic, D.R. Milivojevic M. I. Djuran, J. Nikodinovic-Punic, J. Inorg. Biochem. 155 (2016) 115-128.

[38] T.P. Andrejević, A.M. Nikolić, B.D. Glišić, H. Wadepohl, S. Vojnovic, M. Zlatović, M. Petković, J. Nikodinovic-Runic, I.M. Opsenica, M.I. Djuran, Polyhedron 154 (2018) 325-333.

[39] D.L. Reger, R.P. Watson, J.R. Gardinier, M.D. Smith, Inorg. Chem. 43 (2004) 6609-6619.

[40] D.L. Reger, E.A. Foley, M.D. Smith, Inorg. Chem. 49 (2010) 234-242.

[41] A.S. Potapov, E.A. Nudnova, A.I. Khlebnikov, V.D. Ogorodnikov, T.V. Petrenko, Inorg. Chem. Commun. 53 (2015) 72-75.

[42] A.B.P. Lever, E. Mantovani, B.S. Ramaswamy, Can. J. Chem. 49 (1971) 1957-1964.

[43] K.N. Lazarou, I. Chadjistamatis, A. Terzis, S.P. Perlepes, C.P. Raptopoulou, Polyhedron 29 (2010) $1870-1879$

[44] K.N. Lazarou, C.P. Raptopoulou, S.P. Perlepes, V. Psycharis, Polyhedron 28 (2009) 3185-3192.

[45] U. Kalinowska-Lis, A. Felczak, L. Cheecińska, K. Zawadzka, E. Patyna, K. Lisowska, J. Ochocki, Dalton Trans. 44 (2015) 8178-8189.

[46] K. Nakamato, Infrared Spectra of Inorganic and Coordination Compounds, Second ed., Wiley-Interscience a Division of John Wiley \& Sons, 1979.

[47] Q.-L. Ren, S.-S. Zhao, L.-X. Song, S.-S. Qian, J. Qin, J. Coord. Chem. 69 (2016) 227-237.

[48] A.M. Petrosyan, Vib. Spectrosc. 43 (2007) 284-289.

[49] L.K. Thompson, T.C. Woon, D.B. Murphy, E.J. Gabe, F.L. Lee, Y. Le Page, Inorg Chem. 24 (1985) 4719-4725.

[50] P.L. Caradoc-Davies, L.R. Hanton, W. Henderson, J. Chem. Soc. Dalton Trans. (2001) 2749-2755.

[51] J.-A. Zhang, M. Pan, J.-Y. Zhang, H.-K. Zhang, Z.-J. Fan, B.-S. Kang, C.-Y. Su, Polyhedron 28 (2009) 145-149.

[52] Y. Jiang, C.-F. Zhu, Z. Zheng, J.-B. He, Y. Wang, Inorg. Chim. Acta 451 (2016) 143-147.

[53] M. Giovanni, M. Pumera, Electroanal 24 (2012) 615-617.

[54] G. Shul, M. Weissmann, D. Bélanger, Electrochim. Acta 162 (2015) 146-155.

[55] A. Heyneman, H. Hoeksema, D. Vandekerckhove, A. Pirayesh, S. Monstrey, Burns 42 (2016) 1377-1386.

[56] M.N. Storm-Versloot, C.G. Vos, D.T. Ubbink, H. Vermeulen, Database Syst. Rev. 3 (2010) CD006478.

[57] M.A.M. Abu-Youssef, S.M. Soliman, V. Langer, Y.M. Gohar, A.A. Hasanen, M.A. Makhyoun, A.H. Zaky, L.R. Öhrström, Inorg. Chem. 49 (2010) 9788-9797.

[58] M. McCann, R. Curran, M. Ben-Shoshan, V. McKee, M. Devereux, K. Kavanagh, A. Kellett, Polyhedron 56 (2013) 180-188.
[59] J.A. Romo, C.G. Pierce, A.K. Chaturvedi, A.L. Lazzell, S.F. McHardy, S.P. Saville, J.L. Lopez-Ribot, MBio 8 (2017) e01991-17.

[60] N. Božinović, S. Šegan, S. Vojnovic, A. Pavic, B.A. Šolaja, J. Nikodinovic-Runic, I.M. Opsenica, Chem. Biol. Drug Des. 88 (2016) 795-806.

[61] B.S.R. Mohamed, M. Subramanian, K.P. Shunmugiah, Appl. Microbiol. Biotechnol. 98 (2014) 6775-6785.

[62] K. Krumova, G. Cosa, Overview of reactive oxygen species, in: S. Nonell, C. Flors (Eds.), Singlet Oxygen: Applications in Biosciences and Nanosciences, RSC Publishing, Cambridge, 2016, pp. 1-21.

[63] V.T. Yilmaz, C. Icsel, J. Batur, S. Aydinlik, M. Cengiz, O. Buyukgungor, Dalton Trans. 46 (2017) 8110-8124.

[64] V.T. Yilmaz, C. Icsel, J. Batur, S. Aydinlik, P. Sahinturk, M. Aygun, Eur. J. Med. Chem. 139 (2017) 901-916.

[65] N. Shahabadi, M. Maghsudi, Mol. BioSyst. 10 (2014) 338-347.

[66] N. Shahabadi, S. Kashanian, Z. Ahmadipour, DNA Cell Biol. 30 (2011) 187-194.

[67] A.I. Matesanz, E. Jimenez-Faraco, M.C. Ruiz, L.M. Balsa, C. Navarro-Ranninger, I.E. León, A.G. Quiroga, Inorg. Chem. Front. 5 (2018) 73-83.

[68] M.M. Milutinović, A. Rilak, I. Bratsos, O. Klisurić, M. Vraneš, N. Gligorijević, S. Radulović, Ž.D. Bugarčić, J. Inorg. Biochem. 169 (2017) 1-12.

[69] Y. Shi, C. Guo, Y. Sun, Z. Liu, F. Xu, Y. Zhang, Z. Wen, Z. Li, Biomacromolecules 12 (2011) 797-803.

[70] M. Rendošová, Z. Vargová, J. Kuchár, D. Sabolová, Š. Levoča, J. Kudláčová, H. Paulíková, D. Hudecová, V. Helebrandtová, M. Almáši, M. Vilková, M. Dušek, D. Bobálová, J. Inorg. Biochem. 168 (2017) 1-12.

[71] H.-L. Wu, W.-Y. Li, X.W. He, K. Miao, H. Liang, Anal. Bioanal. Chem. 373 (2002) $163-168$.

72] L. Švorc, K. Kalcher, Sensors Actuators B Chem. 194 (2014) 332-342.

[73] L. de Repentigny, Curr. Opin. Microbiol. 7 (2004) 324-329.

[74] C. Chakraborty, C.H. Hsu, Z.H. Wen, C.S. Lin, G. Agoramoorthy, Curr. Drug Metab. 10 (2009) 116-124.

[75] O.A. Lenis-Rojas, M.P. Robalo, A.I. Tomaz, A. Carvalho, A.R. Fernandes, F. Marques, M. Folgueira, J. Yáñez, D. Vázquez-García, M.L. Torres, A. Fernández, J.J. Fernández, Inorg. Chem. 57 (2018) 13150-13166.

[76] K.M. Brothers, R.L. Gratacap, S.E. Barker, Z.R. Newman, A. Norum, R.T. Wheeler, PLoS Pathog. 9 (2013) e1003634.

[77] N. Branzk, A. Lubojemska, S.E. Hardison, Q. Wang, M.G. Gutierrez, G.D. Brown, V. Papayannopoulos, Nat. Immunol. 15 (2014) 1017-1025.

[78] M.G. Netea, L.A.B. Joosten, J.W.M. van der Meer, B.J. Kullberg, F.L. van de Veerdonk, Nat. Rev. Immunol. 15 (2015) 630-642.

[79] R.L. Gratacap, A.K. Scherer, B.G. Seman, R.T. Wheeler, Infect. Immun. 85 (2017) e00276-17. 